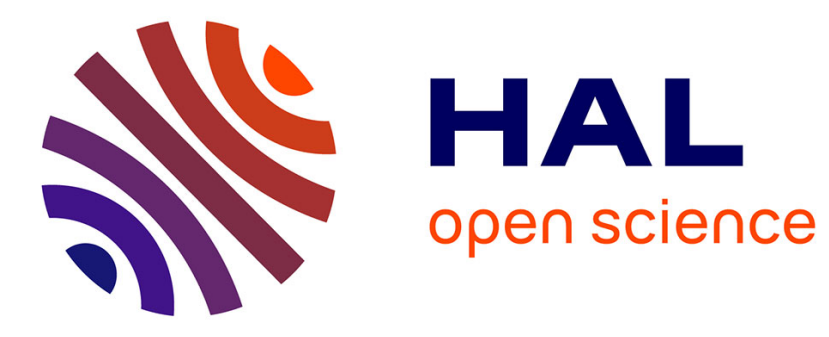

\title{
Mast cells and inflammatory kidney disease
}

Ulrich Blank, Marie Essig, Lisa Scandiuzzi, Marc Benhamou, Yutaka

Kanamaru

\section{To cite this version:}

Ulrich Blank, Marie Essig, Lisa Scandiuzzi, Marc Benhamou, Yutaka Kanamaru. Mast cells and inflammatory kidney disease. Immunological Reviews, 2007, 217 (1), pp.79-95. 10.1111/j.1600065X.2007.00503.x . hal-03208572

\section{HAL Id: hal-03208572 \\ https://hal.science/hal-03208572}

Submitted on 26 Apr 2021

HAL is a multi-disciplinary open access archive for the deposit and dissemination of scientific research documents, whether they are published or not. The documents may come from teaching and research institutions in France or abroad, or from public or private research centers.
L'archive ouverte pluridisciplinaire HAL, est destinée au dépôt et à la diffusion de documents scientifiques de niveau recherche, publiés ou non, émanant des établissements d'enseignement et de recherche français ou étrangers, des laboratoires publics ou privés. 


\title{
Mast Cells and Inflammatory Kidney Disease
}

\author{
by Ulrich Blank ${ }^{1,2}$, Marie Essig ${ }^{1,2,3}$, Lisa Scandiuzzi ${ }^{1,2}$, Marc Benhamou ${ }^{1,2}$ and Yutaka \\ Kanamaru ${ }^{1,2}$ \\ ${ }^{1}$ Inserm U699, Paris, F-75018, France; ${ }^{2}$ Université Paris 7-Denis Diderot, Faculté de \\ Médecine, Site Xavier Bichat, Paris, F-75018, France; ${ }^{3}$ AP-HP, Hôpital Bichat, Service de \\ Néphrologie, Paris, F-75018
}

Corresponding author : Ulrich Blank, Inserm U699, Faculté de Médecine, Site Xavier Bichat, 16 rue Henri Huchard, 75018 Paris, France, Tel : 33 (0)1 44856262 ; Fax : 33 (0)1 44856260 ; email: ublank@bichat.inserm.fr

Total word count including table 1: 14192 


\section{Running title: MC and inflammatory kidney disease}

\section{Summary}

Inflammatory kidney disease involves a complex network of interactions between resident kidney and infiltrating haematopoietic cells. Mast cells (MC) are constitutively found in kidneys in small numbers, but considerably increase in various renal diseases. While this is usually interpreted as a sign of pathological involvement, recent data using MC-deficient animals reveal their ability to restore kidney homeostasis. In anti-glomerular basement membrane antibody-induced glomerulonephritis $\mathrm{MC}$ are protective by initiating repair and remodeling functions counteracting the devastating effects of glomerular injury. Protection may also include immunoregulatory capacities to limit autoreactive $\mathrm{T}$ cell responses. MC cells also control tubulointerstitial fibrosis by activating tissue remodeling and neutralizing fibrotic factors. Release of mediators by MC during inflammation could, however, also promote unwanted responses that ultimately lead to destruction of kidney structure. This is exemplified by data showing either protection or aggravation in related renal disease models. Similarly, while the action of proteases may initially be beneficial, the generation of fibrosis promoting angiotensin II by chymase also demonstrates the limits of adaptive responses to achieve homeostasis. Thus, it is likely the physiological context involving the interaction with other cells and inflammatory mediators that determines the final action of $\mathrm{MC}$ in the development of kidney disease. 


\section{Introduction}

Kidney diseases are complex inflammatory disorders that are either congenital or - in most cases - acquired. The latter involve a variety of mechanisms successive to an injury induced by immunological (Goodpasture disease, lupus nephritis, IgA nephropathy), metabolic (diabetic nephropathy), hemodynamic (hypertension), ischemic (shock) and toxic (antibiotics, fungi) assaults. Independent of their aetiology, they all have in common involvement of an inflammatory process destined to counteract the injurious event, but which can also lead to the development of renal glomerulosclerosis and tubulointerstitial fibrosis with the final consequence of end-stage renal disease when most of the functional filtration units (nephrons) of the kidney have been destroyed. It has been known for quite some time that infiltrating immune cells are major actors in the pathophysiology of disease development including in those that are not of immunological origin (1-3). These cells initiate a complex network of events that include the production of inflammatory cytokines/chemokines and growth factors, local tissue responses, tissue remodeling, cell-cell interactions that together affect the disease process.

Mast cells (MC) are present in virtually every vascularised tissues of the human body including in the kidney. Like in any other tissue, $M C$ are thought to participate in the inflammatory response that follows kidney injury by their ability to secrete a large variety of inflammatory mediators (4). These are either rapidly released from sources prestored in cytoplasmic granules like histamine and unique proteases or after de novo synthesis such as for prostaglandin and leukotriene lipid compounds and for a large set of cytokines and chemokines. MC can also directly interact through direct cell-cell contact with other cells of the immune system such as for example T cells, B cells and dendritic cells (4). Together, these functions participate in the orchestration of the inflammatory reaction by promoting vascular permeability, local tissue responses, attraction of other inflammatory cells and by regulating immune responses. Inflammation is in principle destined for repair of tissue structure and function. However, this function can be compromised due to initial heavy damage, inappropriate persistent stimulation or defective regulation of inflammation. In this 
case chronic inflammatory disease develops with $\mathrm{MC}$ as important components, as is known for pathologies like allergies, asthma, rheumatoid arthritis, etc (4-6). Many recent evidences, however, have emphasized that MC also participate in restoration of homeostasis by their ability to fight bacterial invaders (7) and parasites (7) or to neutralize toxic compounds such as endothelin (8) and venoms (9). MC are also involved in tissue repair mechanisms as they secrete various products such as heparin, proteases, growth factors etc. that are able to regulate the clotting system, fibrinolysis and tissue matrix remodeling $(6,10)$.

Interest about research on MC in the kidney arouse with the discovery that the number of $M C$ in this organ is increased in a variety of diseases (11-13). Crucial were also the findings that infiltrating inflammatory effector cells and associated inflammatory cytokines and chemokines can play an important role in the development of glomerulonephritis (GN) and tubulointerstitial fibrosis leading to end-stage renal failure. This spurred interest to analyze the role of $\mathrm{MC}$ in the kidney in further detail. In the following we review the accumulated data that now include also research carried out using MC-deficient mice or rats in several disease models. They indicate that MC may not necessarily be involved in the development of kidney pathology, but could have a beneficial role to restore normal kidney homeostasis.

\section{Kidney disease and inflammation}

The kidney contains about 1 to 1.3 million nephrons. These are composed of the glomeruli located in the cortex serving as the filtration devices and of the tubules, in which the final concentrate of the urine is composed and electrolyte homeostasis is maintained. The glomerulus is a capillary tuft of afferent and efferent arterioles held together by the mesangium and surrounded by the Bowman's capsule. Within the glomerulus the blood passes a filter composed of the fenestrated vascular endothelial cells, the underlying glomerular basement membrane (GBM), and the visceral epithelial cells or podocytes forming an interdigitating network called foot processes around the capillaries. Filtrated fluid 
and soluble material enter the Bowman's space from where they will leave the glomerulus into the proximal tubules.

Inflammation is a hallmark of kidney disease involving both glomerular and tubulointerstitial structures but has been mostly studied for glomerular diseases. At the acute phase, it is characterized by secretion of various mediators leading to the influx of blood cells, phenotypic changes of resident renal cells and extracellular matrix remodeling. Inflammation often resolves spontaneously with reduction of blood cell infiltration and return to a "normal" phenotype of renal cells after tissue repair, adaptive responses and regeneration. However, in progressive disease it leads to scarring of large parts of the parenchyma with reduction of renal filtration and finally to end-stage renal disease (Fig. 1).

An inflammatory response could be triggered directly by infection or metabolic injury of glomerular cells. Genetic defects in components of the glomerular basement membrane (14) or the slit diaphragm of podocytes (15) have been also incriminated recently in the genesis of glomerular inflammation. However, most of the known mechanisms initiating glomerular injury are immunological disorders including autoimmunity against normal components of the glomerular structure such as in Goodpasture disease, or deposition of immune complexes such as in systemic lupus erythematosus or IgA nephropathy. Deposition of circulating immune complexes may occur in the glomerulus by binding to Fc receptors expressed on mesangial cells in IgA nephropathy (16) or by passive deposition in the mesangium or subendothelial space. In situ formation occurs when antibodies bind directly to intrinsic glomerular antigen or when a non-glomerular antigen deposits in glomerular structures such as cationic proteins which can bind anionic basement membrane.

The molecular nature of the autoantigen is generally not known except in Goodpasture syndrome where the inflammatory reaction involves antibodies, which recognize a specific antigen present in the GBM. The Goodpasture's antigen is a glycoprotein fragment which has been identified as the NC1 domain of $\alpha 3$ chain of type IV collagen, the major component of the mammalian $\mathrm{BM}(17,18)$. The disease is strongly associated with HLA-DR15 and it is speculated that initiating events such as infection, 
exposure to toxins, renal injury, ischemia and various types of neoplasia could expose critical epitopes by altering GBM structure (18). Autoantibodies against glomerular endothelial and mesangial cells have been also reported in some patients with lupus nephritis (19) and autoantibodies against glomerular epithelial cells are postulated to be present in membranous nephropathy (20). Autoantibody synthesis could also occur after bacterial or viral infection or oxidant synthesis such as may occur with smoking or aging. Cell-mediated immunity has been also involved in some GN. T cells sensitized to endogenous or exogenous antigens present in the glomeruli may promote delayed-type hypersensitivity reaction and activate macrophages effector functions. In minimal change disease and primary focal segmental glomerulosclerosis, $\mathrm{T}$ cells have been postulated to induce a permeability factor and injury of podocytes leading to the loss of sieving function of the glomerular basement membrane $(21,22)$. The second most important mechanism of $G N$ is direct injury of glomerular cells, which could result from numerous factors among them viral infection (HIV, HVB), drugs or toxins and metabolic or mechanical stress. Glomerular endothelial injury in thrombotic microangiopathy is one example of inflammatory response resulting from direct glomerular injury. In most cases, it is induced by drugs, toxins, genetic variations in the complement regulatory proteins or the activity of proteases that cleave the von Willebrand factor (23-25). Diabetes is an example of glomerular damage induced by metabolic injury whereas mechanical stress such as flow-induced stretch or shear stress in the remaining nephron is thought to be a major determinant of the progression of renal disease after the reduction in the number of functioning nephrons $(26,27)$.

In immune complex-mediated GN the binding of antibody complexes constitutes the initial trigger for the recruitment and activation of inflammatory cells such as neutrophils or macrophages through activating $\lg G$ or $\lg A F_{c}$ receptor $(F c R)$-dependent mechanisms. These play a crucial role in injury as has been shown in several experimental models of GN (1, 28-30, 31 and Kanamaru et al, submitted). FcR-bearing cells are attracted by and can release factors that induce further damage, such as lysosomal proteases, reactive oxygen species, lipid degradation products, numerous chemokines or cytokines, among which TNF 
could play a major role $(32,33)$. They may also promote the recruitment and activation of $\mathrm{T}$ cells. Inflammatory cell recruitment into glomeruli and interstitial spaces is further enhanced by the expression of adhesion molecules on endothelial cells (34). In parallel, one observes also the activation of the complement system (with the exception of IgAN) through $\mathrm{C} 1$ (classic pathway) or C3 (alternative pathway). This activation leads to the formation of a membrane attack complex that can directly induce tissue damage or indirectly, by recruitment of inflammatory cells $(35,36)$. The massive endocapillary injury induces the activation of the coagulation pathway and stimulates fibrin deposition. Released products may also lead to the recruitment and/or activation of MC. At present it remains unknown whether this takes place during the acute phase of inflammation or during the later phases of disease development or both (Fig.1).

Another hallmark of glomerular inflammation is the phenotypic changes, which occur in resident renal cells. Mesangial and tubular cells have been demonstrated to acquire a proinflammatory and pro-fibrotic phenotype $(37,38)$ while endothelial cells promote the recruitment of inflammatory cells though the expression of adhesion molecules. The ensuing secretion of reactive oxygen species, nitric oxide, lipids-derived factors, cytokines and growth factors further amplifies the infiltration and additionally modifies the behavior of neighbouring cells. This contributes for example to the increased proliferation of mesangial cells leading to the hypercellularity of the mesangial space. Mesangial cells also develop an undifferentiated phenotype of myofibroblasts with the expression of alpha-smooth muscle actin, a molecule abundant on vascular smooth muscle cells (37). The activation of tubular cells is thought to result from proteinuria (39) or directly through the complement fragments or other inflammatory mediators present in the urine fluid (40). Proteinuria resulting from glomerular damage is able to activate tubular cells and to induce toxicity either directly or via the generation of oxidant products or complement activation. Like mesangial cells, activated tubular cells have been demonstrated to release chemotactic factors among which MCP1, osteopontin and TGF- $\beta 1$ seem to play a major role by inducing the recruitment of monocytes/macrophages and lymphocytes in the interstitial space (41-43). Activated tubular 
cells are also able to proliferate or "trans-differentiate" into myofibroblats with pro-fibrotic activity (44). The main characteristic of phenotypic changes in podocytes is structural alterations of the foot processes and slit diaphragm leading to proteinuria. Podocytes have the capacity to replicate and to populate glomerular crescent (45), but they usually engage in a defective cell cycle finally leading to loss of several differentiation markers of podocytes such as WT1, synaptopodin or nephrin. These undifferentiated podocytes seem no longer able to support normal capillary tuft function thus leading to the development of glomerulosclerosis (46).

The other major histological feature of $\mathrm{GN}$ is the imbalance between extracellular matrix synthesis and proteolysis leading to the deposition of abnormal extracellular matrix containing new constituent of collagen such as interstitial collagen I and III, while collagen IV is the only collagen component in the normal glomerular basement membrane (47). An increased synthesis in collagen IV and other components of the extracellular matrix has been shown in mesangial cells during the course of GN mostly induced by pro-fibrotic molecules such as TGF- $\beta 1$ (48). The latter also increases the synthesis of the tissue inhibitors of metalloproteinases and the type 1 inhibitor of the plasminogen activators (PAI-1) (49), which inhibits the degradation of ECM components as well as of fibrin by the plasminogen/plasmin pathway. Of note, fibrin is an important mediator of glomerular injury and deficiency in plasminogen, combined deficiency in tissue type plasminogen activator and urokinase type plasminogen activator or urokinase receptor are associated with severe functional and histological exacerbation of glomerular and tubular injury (50).

Mechanisms involved in the resolution of glomerular or tubular injury include clearance of inflammatory blood cells, return to a normal number of resident renal cells and remodeling of the extracellular matrix in order to restore high order structures. Clearance of neutrophils is mostly done by local apoptosis (51) whereas macrophages seem to migrate via the lymphatic vessels perhaps to undergo apoptosis in draining lymph nodes (52). Apoptosis of mesangial and endothelial cells is another hallmark of the resolution of glomerular injury $(53,54)$. However, unscheduled apoptosis of glomerular cells, especially 
podocytes, may lead to a hypocellular, nonfunctional scar. Indeed, podocyte loss has been involved in the genesis and the severity of numerous $\mathrm{GN}(55,56)$

\section{Mast cells in the kidney}

\subsection{Localisation and characteristics of MC in normal and pathologic kidneys}

MC can be identified by histologic analysis using their specific granular content of proteoglycans that stain with metachromatic dyes such as toluidine blue. They can be also identified using immunohistochemical staining with anti-tryptase and anti-chymase antibodies. Large differences have been noted when applying the two methods for the detection of human renal MC in that immunohistochemical detection allows to identify much higher numbers of $\mathrm{MC}(11)$. It should be noted that under some circumstances hypervacuolated cells with a paucity of metachromatic cytoplasmic granules have been observed in various inflamed epithelia, including in cortical tubular epithelium (57). Such cells, which could represent degranulated $\mathrm{MC}$ are not necessarily detected by classical methods, but can be revealed for example by electron microscopy.

Already early on it was reported that $\mathrm{MC}$ increase in numbers in the renal interstitium of various human kidney diseases $(57,58)$. The presence of MC was also found in kidney (glomerulus, interstitium and tubules) of rats to which a magnesium deficient diet was administered (59). The first immunohistochemical study with anti-tryptase antibodies was published in the 1996 and demonstrated again that MC numbers increased in response to an acute cellular rejection of human renal allografts (60). Table 1 summarizes the data obtained for normal MC and various renal pathologies from several reports in the literature $(57,61-67)$. They show that normal kidney parenchyma contains only few MC. However, in various renal diseases their occurrence often strongly increases over that in normal kidneys. In most cases this also correlates with the serum concentration of creatinine and with the intensity of tubulointerstitial injury and fibrosis (66). It should be noted, however, that considerable heterogeneity exists among patients, reflected also by the important standard deviations observed in these studies including our own (M. Essig, unpublished). Most MC were found in 
the interstitial space where they concentrate in areas close to blood vessels, tubular structures, mononuclear cell infiltration and fibrosis $(65,66)$. Although periglomerular localisation was also noted, they were never found in the glomeruli. An example for the scattered distribution of tryptase positive MC in lupus nephritis patients is shown in Fig. 2. In some diseases such as chronic GN or pyelonephritis, tubular MC were also observed. As already mentioned, these contain a high proportion of hypervacuolated cells that stain poorly using classical methods and may correspond to degranulated MC (57).

As various subtypes have been defined on the basis of protease content, analysis of kidney MC have also included the study of MC subtypes. They indicate that kidneys contain three subtypes, which are tryptase positive mucosal-type $M C\left(M_{T}\right)$, double-positive tryptase-chymase connective tissue type $\mathrm{MC}\left(\mathrm{MC}_{\mathrm{TC}}\right)$ and a third chymase-positive phenotype $\left(\mathrm{MC}_{\mathrm{C}}\right)$, which was, however, observed very rarely. In normal kidneys, although the overall number is low, both tryptase and chymase staining cells are present with the numbers of the former being about twice the number of the latter $(61,63)$. This suggests that both $\mathrm{MC}$ subtypes are present with tryptase positive cells slightly outnumbering the tryptase-chymase positive cells. The ratio of $\mathrm{MC}$ subtypes $\left(\mathrm{MC}_{\mathrm{T}}\right.$ and $\left.\mathrm{MC}_{\mathrm{TC}}\right)$ in the renal interstitium seems to be different among renal diseases. In rapidly progressive $\mathrm{GN}$, the $\mathrm{MC}_{\mathrm{T}}$-type was dominant (64) as it is in normal kidneys. By contrast, IgA nephropathy and diabetic kidneys had many $\mathrm{MC}_{\mathrm{TC}}$-type $\mathrm{MC}(65,68)$. In rejected transplanted kidneys, the ratio of $\mathrm{MC}_{\mathrm{T}}$ and $\mathrm{MC}_{\mathrm{TC}}$ was variable, and $\mathrm{MC}_{\mathrm{C}}$-type $\mathrm{MC}$ were present (68).

In another study a distinction between two groups of patients could be made, those with relative increase ( 9 -fold) in tryptase-positive cells (Chy- group) and those with a relative increase of both tryptase $(\sim 14-$ fold $)$ and chymase $(\sim 18$-fold $)$ positive cells (Chy+ group) cells (63). The latter group also contained significant numbers of cells that stained positive with chymase only $\left(\mathrm{MC}_{\mathrm{C}}\right)$. An increase of both tryptase-positive and chymase positive cells was also observed in diabetic nephropathy patients (61). In contrast to these reports, another study performed on renal tumor specimen reported that renal MC contained tryptase, but only low or undetectable amounts of chymase (62). Isolated MC from the tumors could be 
stimulated via IgE receptors but not with complement fragment C5a known to be present only on $\mathrm{MC}_{\mathrm{TC}}$. Thus, this report suggested that renal $\mathrm{MC}$ contained essentially $\mathrm{MC}_{\mathrm{T}}$ cells that do not express receptors for complement fragments.

The increase in the number of MC and correlation with the severity of disease has often been interpreted in that MC could play a pathogenic role in renal disease. However, clear evidence for this has not been presented in many of these studies. More recent data suggest that MC can also have beneficial roles and that besides infiltrating cells, systemic effects of $M C$ or immunologic processes initiated by $M C$ in adjacent lymph nodes could be also important (see below).

\subsection{MC growth factors in kidney}

It is currently unknown, how MC are recruited into kidneys, although one important factor could be stem cell factor (SCF), the prototypic growth factor for MC. Indeed, evidence has been presented showing an increase of SCF in patients with renal disease. Kitoh et al showed that serum levels were elevated by about 5 -fold in patients with end-stage renal failure (69). Further analysis revealed that higher levels correlated closer with blood renal function parameters than with red blood cell counts and haemoglobin levels, which are also affected in renal disease. This suggested a relationship with the deterioration of renal function. A significant correlation between the number of interstitial MC and serum SCF levels was also observed in patients with anti-neutrophil cytoplasmic autoantibody (ANCA)associated GN (70). Direct immunohistochemical analysis of SCF in human kidney $(71,72)$ revealed that SCF was barely detectable in normal kidney, but that there was a marked upregulation in GN patients who developed chronic renal failure. SCF was both cellular and interstitial and correlated with the number of MC. It appeared to localize in areas of interstitial expansion and fibrosis. Cell-associated SCF was detectable primarily in tubular cells and interstitial infiltrating cells. SCF was also detected in cells within the glomeruli. Whether these cells produce SCF and attract MC to the kidney remains, however, to be determined. 
Another important factor involved in selectively promoting the appearance of $M C$ in kidney could be IL-9, one of the cytokines produced by activated TH2 lymphocytes known to enhance MC survival, proliferation and expression of MC-specific products. It was found that IL-9-deficient mice have lower numbers of MC and are severely impaired in their capacity to develop mastocytosis in synchronous pulmonary granuloma formation upon injection of Schistosoma mansoni eggs (73). In IL-9 transgenic mouse, MC hyperplasia has been observed in the gastric and intestinal epithelia, the trachea and in kidney epithelium but not in the skin (74). The number of MC increased in the epithelial layer of renal tubules in this transgenic mouse, although degranulation of the $\mathrm{MC}$ did not occur in contrast for example to IL-4-transgenic mice where piecemeal degranulation and fibrosis in lesions of the eyelids were observed (75). However, neither degranulation of $\mathrm{MC}$ nor increase in $\mathrm{MC}$ number has been reported in the kidney of this mouse. Interestingly, MC from IL-9 transgenics showed a phenotype related to connective-type MC staining positive for both tryptase and chymase even at mucosal sites indicating some specific importance of IL-9 in MC differentiation. As indicated above it was shown that MC in renal diseases exhibit a highly heterogeneous phenotype in the expression of MC proteases. It is therefore possible that variable levels of IL-9 in renal disease could play a role in determining this heterogeneity. In vitro, IL-9 was unable to induce MC growth and differentiation; however, it clearly had synergistic activity with IL-3 and SCF, the classical growth factors of murine MC, and also strongly influenced the pattern of expression of MC proteases. Although IL-9 has been shown to play a role in differentiation of murine MC in the kidney, no evidence exists as of yet concerning the role of IL-9 in human disease.

Besides SCF and IL-9 other chemokines that are expressed during the inflammatory response in injured kidneys may contribute to the recruitment of $\mathrm{MC}$. MC were shown to express a large variety of chemokine receptors (76) amongst which for example CCR1 and CCR3 that can bind MIP1 $\alpha$, eotaxin and RANTES $(77,78)$. Besides mediating chemotaxis, the interaction with chemokine receptors may also induce cross-talk signals that can amplify or inhibit specific MC responses (77). TGF- $\beta$, one of the major factors involved in 
tubulointerstitial fibrosis (see below) has been also described as a powerful chemoattractant for MC (79).

\subsection{MC mediators in the kidney}

MC have a unique set of receptors allowing them to respond in a variety of physiological situations, for example in immune defense mechanism or in inflammatory responses, with the secretion of a large variety of inflammatory mediators. Some are released from sources prestored in cytoplasmic granules, others are newly synthesized upon activation. The contribution of mediators released by $M C$ to renal disease is not well documented. In the following we try to summarize some of the potential actions of MC released products in renal disease mechanisms.

Although MC-released histamine is known as a potent vasodilator, so far this mediator has not been incriminated in the development of kidney disease. Its secretion into urine seems to be decreased in patients with proteinuria, which could be a result of a compensatory hemodynamic response to limit urinary protein losses (80). By contrast, proteases like tryptase and chymase also released from cytoplasmic granules could represent major players in kidney diseases. Tryptase is one of the most abundant mediators stored in cytoplasmic granules and has potent proteolytic activity (against fibronectin, calcitonin gene-related peptides, kininogen ...) that could also be relevant in kidney disease (81). It has remarkable resistance to inhibition by blood plasma proteinase inhibitors and its activity is increased at acidic $\mathrm{pH}$ such as may occur at inflammatory sites. It has been reported that MC-derived tryptase might act as a link to fibrosis development as it supports fibroblast proliferation via the activation of protease activated receptors (82) and the synthesis of type I collagen (83). Tryptase also caused the increase in DNA synthesis of renal fibroblasts in vitro, especially when co-incubated with heparin and also increased the synthesis of collagen I of cultured renal fibroblasts (84). Tryptase can also interfere with the blood clotting system by direct inactivation of fibrinogen and thus work as a coagulation prevention factor (85). Cleavage also significantly reduced fibrinogen binding to endothelial 
cells (86). These activities could be important in GN development, which is significantly diminished in fibrinogen-deficient mice (87). Another MC-specific protease is chymase, which is a serine protease with chymotryptic activity. MC chymase may have antithrombotic functions as mouse MCP-4 chymase has been known to inactivate thrombin (88). MC chymase also plays a key role in the activation of matrix metalloproteinases such as MMP-2 and MMP-9 by its capacity to process the proforms to the active forms and thus promoting connective tissue homeostasis (89). This effect may be enhanced by the ability of chymase to cleave one of the endogenous inhibitors TIMP-1 (90). Recently it has been reported that MC chymase and another secreted protease carboxypeptidase A can also degrade endothelin-1, a 21-aa peptide with potent vasoconstrictor and proliferating properties (8). Endothelin-1 can be produced by renal tubular cells and has been incriminated to participate in the interstitial inflammation in various renal disease models (91). Chymase may also contribute significantly to kidney pathology by its ability to generate Angiotensin-II (Ang II) in addition to Angiotensin Converting Enzyme (ACE) activated by the kidney-localized reninangiotensin system (92). Ang II increases the blood pressure and independently also contributes to fibrosis development by its potent pro-inflammatory activity that induces the expression of cytokines, chemokines, adhesion molecules, growth factors and reactive oxygen species (93). Recent study in ACE-knockout mice has shown that local Ang II generation within the kidney is unchanged due to an upregulation in the chymase activity (94). Of note, rat MC chymase has been demonstrated to cause an increase in epithelial permeability and alters the distribution of tight junction proteins (95).

Besides granule-stored enzymes MC secrete also large amounts of proteoglycans, notably heparin. Besides its role in the storage of granule proteases, heparin has been known for long for its potent anti-thrombotic activities. It has been known also as an antiinflammatory agent, an activity that is uncoupled from its anticoagulant properties in multiple pathophysiologic situations, but which is still poorly characterized (96). Heparin has also been shown to modulate mesangial cell proliferation. 
In addition to granule-released products $\mathrm{MC}$ also newly synthesize mediators amongst which are arachidonic acid metabolites such as the leukotriene (LT) and prostaglandin (PGD) compounds (97). Although these can be produced by a variety of other inflammatory cells, it has been shown that MC-derived LTB4 serves as a powerful and rapid chemoattractant for effector CD8-positive T cells but not memory $T$ cells (98). As effector $T$ cells are also involved in GN development such a mechanism could be also relevant in the pathological mechanisms that promote injury in the kidneys. The lipid derived products also represent important stimuli for intrarenal vasoconstriction and mesangial cell contraction.

Besides heparin, MC can produce a variety of other products that affect the blood clotting system. Notably, it has been reported that human tissue MC and the human MC line HMC-1 constitutively produce tissue plasminogen activator tPA known to convert the fibrinolytic enzyme plasminogen from its pro-form into plasmin. Upon activation by complement fragment $\mathrm{C} 5 \mathrm{a}$ they also produce the endogenous plasminogen inhibitor 1 (PAI1) in excess over tPA. Given that plasmin can inactivate C5a this suggests that complement fragment-mediated activation could be controlled both in an autocrine and paracrine fashion. On the other hand, as described above, other MC products such as tryptase may have potent fibrinolytic activities. Thus, it is difficult to judge what will be the net action under physiological or pathophysiological conditions in vivo, although most of the actions seem to be in favour of a balance for a net fibrinolytic activity. Given that fibrin deposition constitutes an aggravating factor in GN (50) this could indicate a beneficial action of MC in GN.

$\mathrm{MC}$ are probably the cell-type known to secrete the largest variety of growth factors, cytokines and chemokines involved in inflammatory responses. Some like TNF $\alpha$, MCP-1, FGF, VEGF and TGF- $\beta 1$ are known to be directly involved in kidney pathology as revealed in a variety of animal models (see below). However, given that other resident and infiltrating cells involved in the inflammatory response in kidney disease can also synthesize these products, it is likely to observe redundancy. Thus, it will be difficult to judge the relative contribution of the MC-produced factors. 
Besides the action of inflammatory products, MC may play an important role in kidney disease by directly influencing the immunoregulatory responses involved such as for example in autoimmune- or immune complexes-mediated kidney diseases. It has been known for many years that MC are important effectors in the development of certain $\mathrm{T}$ cellassociated responses, likely by providing some essential co-factors such as TNF $\alpha$ (99). Recently, MC have been shown to represent an essential intermediate for the development of $\mathrm{B}$ cell responses in immune complex autoantibody-driven arthritis (5). Contrary to these proinflammatory properties of $M C$ that may be relevant in many diseases, $M C$ have been recently involved in the regulation of immunosuppression. Thus, they were shown to be essential for the development of regulatory $\mathrm{T}$ cell (Treg)-dependent peripheral tolerance against skin allografts (100). Importantly, it appears that IL-9 is an essential T cell product that recruits and activates $\mathrm{MC}$ to mediate the regional immune suppression.

\section{Role of MC in kidney diseases}

\subsection{MC in anti-GBM-induced glomerulonephritis}

In GN the normal function of filtration is affected following an inflammatory process. Although MC have been observed in increased numbers in human GN it is difficult to judge their participation in disease as usually a number of other inflammatory cells are seen to infiltrate the kidney. Furthermore, systemic effects independent of the inflammatory cell infiltrate cannot be excluded as the kidney represents a particularly highly irrigated organ. One possibility to dissect the roles of MC in various inflammatory diseases is by the analysis of experimental disease models in $\mathrm{WBB} \mathrm{F}_{1}-\mathrm{Kit}^{\mathrm{W} / \mathrm{W}-\mathrm{v}}$ mice that genetically lack $\mathrm{MC}$ due to two mutations in the MC growth factor receptor for SCF c-kit. $W / W^{N}$ mice ordinarily have $<1 \%$ the wild-type levels of skin MC and usually no detectable $M C$ in the peritoneal cavity, respiratory system, gastrointestinal tract or other sites. These mice can be specifically reconstituted with $M C$ to effectively show that the observed phenotype is indeed due to the absence of MC and not any one of the other deficiencies (anaemia, melanocytes etc) seen in these mice (4). 
Researchers have begun to study the role of $M C$ in glomerular diseases using $W W^{N}$ mice in an experimental model of Goodpasture disease initially developed by Masugi, which involves the injection of antibodies directed against the GBM (101). The Masugi's model is characterized by a heterologous phase that follows the injection of the heterologous antiGBM antibodies. This phase is characterized by a rapid (within one hour) and massive, but transient influx of neutrophils that, through FcR- and complement-dependent mechanisms, leads to the initial glomerular injury and proteinuria. This is followed by an autologous phase that develops after the host mounts its immune response to the injected antibodies $(28,29$, $35,101)$. The latter can be accelerated when hosts are preimmunized with normal IgG in complete Freund's adjuvant a few days before injection of the anti-GBM antibody. The autologous phase is characterized by the infiltration of a second set of inflammatory cells such as FcR-bearing macrophages and $T$ cells that are also effectors of injury and further promote disease development towards renal failure. The importance of $\mathrm{T}$ cell responses has been demonstrated in several studies. They suggest a role for CD4 T cell driven TH1-type responses with development of delayed-type hypersensitivity-like cellular effectors (CD8 T and macrophages) as well as TH1 lg isotype production (102). Recently, defects in regulatory T cells have been implicated as a potential mechanism of pathology (103).

Three different studies have analyzed the role of MC in anti-GBM-induced GN using MC-deficient mice with, however, somewhat different outcomes and conclusions. While both in our study (104) and the study of Hochegger et al (105) MC were protective, they were disease-aggravating in the study of Timoshanko et al (106). In our study, following injection of the anti-GBM serum, disease developed rapidly and MC-deficient $W W^{N}$ mice showed high mortality that appeared already during the early heterologous phase. Essentially all MCdeficient mice died within 14 days, while +/+ mice showed high survival rates. Reconstitution of the MC population in $\mathrm{W} / \mathrm{W}^{\vee}$ mice restored the protection confirming that mortality was indeed due to the absence of MC. Histological analysis revealed as a striking feature the presence of thick layers of subendothelial deposits in $\mathrm{W} / \mathrm{W}^{v}$ mice, while $+/+$ mice or $\mathrm{MC}$ reconstituted $\mathrm{W} / \mathrm{W}^{\vee}$ mice showed much less. These deposits appeared during the early 
phase of the disease and persisted thereafter. They were accompanied by elevated glomerular macrophage infiltration in $W / W^{N}$ mice, while $\mathrm{T}$ cells were essentially absent as glomerular infiltrate with no differences noted between the groups of mice. We also noted an absence of $\mathrm{MC}$ infiltrate in the wild-type mice suggesting at the same time the possibility that the MC effect could be due to systemic activation of MC. Further analysis revealed that the deposits contained fibrin and type I collagen that were significantly increased in $W W^{N}$ mice. In agreement with high amounts of fibrin, $W W^{N}$ mice were unable to maintain high tissue plasminogen activator (tPA) and urinary-type plasminogen activator (UPA) activity in urine at the late phases of the disease. It is known that fibrin is a key factor in GN development and contributes to the rapid progression of the disease as shown in fibrinogen-deficient mice (87). Based on this we suggested that the protective action of MC was due to their capacity to mobilize remodeling and repair functions. We also analyzed the contribution of MCexpressed activating Fc receptors in the protective effect by reconstituting $W W^{N}$ mice with MC derived from mice lacking $\mathrm{FcR} \gamma$, the common subunit of activating FcR. No significant differences were seen as compared to mice reconstituted with $M C$ from wild-type mice suggesting that protection was mostly independent of the activation of FcR. Other stimuli may include complement fragments such as $\mathrm{C} 3 \mathrm{a}$ or $\mathrm{C} 5 \mathrm{a}$, endothelin or other inflammatory mediators that could be produced during the initial inflammatory phase of the disease $(4$, $101,107)$. In the study of Hochegger et al (105) the authors also found an increased mortality after administration of anti-GBM antibodies in $W W^{\nu}$ mice as compared to $+/+$ mice or $W / W^{N}$ mice reconstituted with bone marrow cells. The rise in mortality appeared, however, relatively late in the disease and became apparent essentially between day 14 and day 21 . Similar to our study $W / W^{N}$ mice contained thick subendothelial deposits. The authors also found increased numbers of macrophages in the interstitium of $W / W^{N}$ mice and surprisingly also highly increased numbers of interstitial CD4 and CD8-positive T cells at day 14 and 21, that were not observed in our study. In addition, they found considerable infiltration with MC of the draining lymph nodes while, like in our study, MC were virtually absent in the kidney. Based on this the authors suggested that MC may be able to induce protection by their ability 
to modulate the influx of effector $\mathrm{T}$ cells and macrophages to the inflammatory sites in the kidney. They speculated that the absence of MC could disturb the anti-inflammatory counterbalance exerted by regulatory $\mathrm{T}$ cells. In a third study, the authors used a non-accelerated model of the disease by injecting the antibodies in two individual doses in the absence of adjuvant and most of the collected data were scored at day 21. Under these condition $W W^{N}$ mice were found to have decreased dermal DTH responses to the injected antibodies, a lesser number of crescentic glomeruli, interstitial infiltrate, glomerular $\mathrm{T}$ cells and macrophages as compared to $+/+$ mice or $W W^{\nu}$ mice reconstituted with $\mathrm{MC}$. Examination of renal parameters revealed less serum creatinine and urinary nitric oxide in $W / W^{\nu}$ mice as compared to the control groups, while no difference was found in proteinuria. Immunohistochemical data revealed an augmentation of glomerular adhesion molecule expression. Taken together, they suggested that MC by their ability to promote $\mathrm{TH} 1-$ dependent effector mechanisms and to enhance glomerular expression of adhesion molecules aggravate the anti-GBM-induced inflammatory response.

Although the three studies come to somewhat different conclusions, these differences may be explainable, when one considers the apparent differences between the models. Together they may actually reveal the high versatility and sometimes contrasting function of the MC as an effector of inflammation. We propose that in our study due to the strong inflammatory potency of the injected anti-GBM antibodies and the use of the accelerated disease model, the capacity of $\mathrm{MC}$ to react to damage with acute effector mechanisms of tissue repair and remodeling that counteracts the injurios process is revealed (Fig 3). In the second study disease develops more slowly, likely due to the use of an antiserum with less injurious potential. In this case, however, an accelerated model is used that promotes recruitment of $M C$ into the draining lymph node to induce regulatory $T$ cells that counteract the development of $\mathrm{T}$ cell dependent effector mechanism during the autologous phase, which thus dampen disease development. Such a mechanism may also be operative in our study during the late phase of the disease. In the third model due to a more slowly developing disease in the non accelerated model, MC rather are contributory in mounting a TH1-directed 
DTH-mediated immune response that promotes injury. Thus, these studies reveal that MC are able to exert a continuous spectrum of biological activities ranging from protection to aggravation in a similar disease model. The outcome of their action very much depends on the pathophysiological environment that directs the MC action.

\subsection{MC in Lupus nephritis}

MC have been also involved in systemic lupus erythematosus (SLE) pathogeny. SLE is an autoimmune disease that predominantly affects females. It involves autoantibodies, mostly produced against DNA, that result in circulating immune complexes depositing in various organs and tissues such as skin, joints, the nervous system and kidney. The resulting inflammation leads to various manifestations such as dermatitis, arthritis, neurologic disorders and also GN. In fatal cases, GN was a leading cause of death until the advent of renal dialysis and transplantation. However, the presence or absence of renal lesions is still critical for the outcome of SLE since they could lead, if unchecked, to renal failure.

The involvement of MC in at least some of SLE manifestations, such as nephritis, has been suspected early on (108). In kidney, the number of tubulointerstitial MC shows a 10-fold increase in SLE nephritis patients compared to healthy individuals and correlates with the fibrotic development $(66,68)$. However, no correlation was found between tubulointerstitial MC number and the clinical outcome of lupus nephritis (109), strongly indicating that although MC may contribute to the disease in this organ they are not the only factor involved. Furthermore and at contrario, MC may play some protective role as reported in an experimental model of pristane-induced lupus nephritis (110) induced in MC-deficient $W W^{\nu}$ and MC-sufficient +/+ mice. The absence of MC led to a diffuse proliferative GN instead of focal segmental GN, and to somewhat more important immune deposits in the glomeruli. However, proteinuria was not significantly affected by the absence of MC. Therefore, both deleterious and protective functions of $M C$ in the kidney may be at work in this disease, rendering more difficult the elucidation of every aspect of their complex involvement in lupus nephritis. 


\subsection{Atopy and kidney diseases}

A relationship between atopy and kidney diseases has been documented for a number of cases. In one instance, increased IgE levels with what appeared to be an allergic reaction to antibiotic therapy was accompanied by interstitial nephritis (111). In lupus nephritis, an increased level of serum $\operatorname{IgE}(112,113)$ and of $\lg E$ deposits in glomeruli $(114)$ have been reported and these correlated with the activity of the disease $(113,115)$. But no correlation was found with an allergic disorder and the involvement of basophils rather than MC was suggested (116).

A number of studies have explored the involvement of atopy in nephrotic syndrome (NS) in adults and children. This syndrome is characterized by heavy proteinuria, oedema and decreased urine excretion. Early observations reported an association between hypersensitivity to a number of allergens with NS (117, 118 and ref therein). In later reports food allergens were also implicated $(119,120)$. More importantly, NS could be induced in NS patients following reintroduction of food allergen into the diet after a period of allergen-free diet (119). Accordingly, allergen avoidance was shown to result in improvement of the status of patients whether the allergen was a food or an inhaled allergen (119-121). As well, a hyposensitization protocol was able to improve the clinical course or even to apparently cure the patients (121). Following all these reports, the IgE levels in NS patients were analysed and increased levels of serum IgE were observed $(112,122-125)$. Furthermore, circulating basophils were found to be sensitized with allergen-specific serum $\lg E$ (126) and $\lg E$ deposits were also detected in glomeruli of patients with NS (127). Yet, some investigators could not reproduce some of these observations (128) and treatment of NS patients with anti-allergic drugs that act on MC led to variable results $(117,129)$. The involvement of the $\lg \mathrm{E} / \mathrm{MC}$ system was discussed in some cases of atopy-associated NS, leaving open the question of MC involvement in this disease (119). However, the ability of this cell and of its circulating counterpart, the basophil, to release vasoactive compounds that could increase permeability of capillaries in the glomeruli, could favor proteinuria. But since only a tiny 
proportion of allergic patients have NS, allergens, IgE and MC must play an aggravating rather than a central role in this disease. The exact mechanism of this involvement is still unresolved.

\section{Role of MC in tubulointerstitial fibrosis}

The development of fibrosis is a common and central feature of all progressive renal diseases that lead to end-stage renal failure (130-133). It involves a complex multistage inflammatory process with mesangial and fibroblast activation, tubular epithelial to mesenchymal transition (EMT), inflammatory cell infiltration, cell apoptosis and extracellular matrix expansion that is orchestrated by a network of cytokines/chemokines, growth factors, adhesion molecules and signaling processes. Due to the adaptive process in the remaining nephrons it is not until about $75 \%$ of the individual nephrons are lost that end-stage renal failure is diagnosed. In comparison to wound healing, it is likely the duration and strength of the inflammatory phase and chronicity that limit regeneration of normal parenchyma and thus finally engenders the loss of numerous functional nephrons by the fibrotic process. There is abundant evidence that the long term outcome of chronic renal disease depends to a great extent on changes within the tubulointerstitial compartment. This includes conditions in which the primary injury and inflammatory response is within the glomeruli. The extent and severity of interstitial fibrosis and tubular atrophy are therefore the most powerful histological markers of renal function and long term prognosis even in chronic $\mathrm{GN}(134,135)$.

As stated above the fibrotic process is characterized by an interstitial chronic inflammatory cell infiltrate, which often also includes MC. Several in vitro studies have pointed out the potential of $\mathrm{MC}$ to induce fibroblast proliferation and collagen synthesis (136). MC tryptase, by virtue of their capacity to activate fibroblast-expressed protease activated receptors eventually in conjunction with heparin, could be an important mediator in this effect (84). MC chymase could also play a role. Indeed, chymase-positive nephrectomy patients showed significantly increased interstitial fibrotic areas in the kidney as compared to chymase-negative 
patients (63). It has been known for long time that chymase is also involved in the generation of profibrotic angiotensin II and can replace angiotensin-converting enzyme in this activity (137).

Numerous studies exist in a variety of tissues and clinical situations in which fibrosis and concomitant MC hyperplasia and activation have been observed. Thus, increased MC numbers have been seen in keloids and in hypertrophic scars (138). MC are also prominent in interstitial pulmonary fibrosis (139) and elevated histamine levels in the bronchoalveolar lavage (BAL) in patients with pulmonary fibrosis have been reported (140). A correlation exists between fibroblast activation and MC counts in the BAL obtained from patients with sarcoidosis, suggesting a relationship between $\mathrm{MC}$ and the progress of connective tissue changes in sarcoid lung (141).

Although the in vitro studies and the correlation of MC infiltration with various diseases suggest their implication in organ fibrosis, the in vivo studies carried out in MC-deficient mice or rats reveal a complex picture and range from a protective to a disease promoting effect. Thus, MC-deficient rats showed exacerbated adverse cardiac remodeling and cardiac fibrosis and worsened diastolic functions in a model of homocysteine-induced cardiac remodeling indicating a protective role (142). Mixed results were obtained for the role of $\mathrm{MC}$ in experimental pancreatic fibrosis. While no crucial role was observed in closed duodenal loop-induced pancreatitis using MC-deficient $W^{\mathcal{S}} W^{\mathcal{S}}$ rats (143), some protective effect was seen in a more long-term model ( 2 weeks) induced by intraperitoneal injection of a superoxide dismutase inhibitor that induced accumulation of reactive oxygen species in the pancreas. Here, significantly less fibrosis were observed in +/+ as compared to $W^{\mathcal{S}} W^{\mathcal{s}}$ rats and this was correlated to MC counts. By contrast acinar fat replacement or atrophy and inflammatory cell infiltration were increased in $+/+$ animals (144). Two studies examining the role of $M C$ in experimental liver fibrosis models studied in MC-deficient rats or mice concluded that MC do not play a major role in the development of liver fibrosis $(145,146)$. Similar results were also seen in a model of bleomycin-induced pulmonary fibrosis with no significant differences revealed for histological changes and hydroxyproline content in the lungs of $W / W^{N}$ mice and $+/+$ mice (147). Conversely, the direct examination of the role of $M C$ in an experimental model of chronic 
asthma using MC-deficient mice has revealed that $\mathrm{MC}$ participate in multiple features of the long-term changes in asthma. This includes the infiltration with eosinophils and lymphocytes, airway epithelial goblet cell hyperplasia, enhanced expression of mucin genes and collagen (148). It should be noted, however, that in this model MC also significantly contribute to the disease initiation via activating FcR-dependent mechanisms, although some FcR-independent processes may also contribute to the long-term disease process especially in the WBB6F1 background.

These data in various disease models have revealed a highly contrasting picture that may also relate to the specific pathological conditions in the various organs. Not all of the studies have rigorously controlled the implication of $M C$ through reconstitution studies. It is also possible that some of the MC functions may be redundant and be taken over by other cells in their absence. Furthermore, kinetic constraints of the various disease models could be important as MC may play a different role in early fibrotic processes as compared to ones that evolve at later periods. Also, the number of infiltrating $M C$ is not the same in the various organs.

Independent of these considerations MC might also play a role in renal fibrosis as several studies show increased $M C$ infiltration in the renal interstitium, tubules and periglomerular areas in various renal diseases. Usually their numbers were correlated with the progression of fibrosis and renal functions such as the $24 \mathrm{~h}$ creatinine clearance $(11,13,65$, 66). However, direct evidence that MC actually cause fibrosis is scarce, although some studies pointed out the specific expression of fibrinogenic molecules in the infiltrated MC population. Thus, type VIII collagen mRNA expression was detected in the cytoplasm of MC in diabetic nephropathy (61). Furthermore, basic FGF that acts as a fibroblast-proliferative factor was expressed in MC in IgA nephropathy (65). MC activity may also relate to TGF- $\beta 1$. It is well accepted that TGF- $\beta 1$ and TGF- $\beta$-initiated Smad signaling pathways are key effector mechanisms for the development of tubulointerstitial fibrosis $(43,149,150)$. TGF- $\beta 1$ is involved in tissue fibrosis including renal fibrosis based on its capacity to induce extracellular matrix (ECM) production, differentiation of fibroblasts into myofibroblasts and apoptosis. TGF- $\beta 1$ has 
potent $\mathrm{MC}$ chemotactic activities and was demonstrated to be associated with $\mathrm{MC}$ infiltration in progressive renal diseases $(79,151-153)$. Furthermore, $M C$ in the injured kidney were found to contain TGF- $\beta 1$ (154). Although, they may not be the only producing cells, this suggested a role in renal fibrosis.

To directly assess the role of MC in fibrosis Miyazawa et al utilized the puromycin

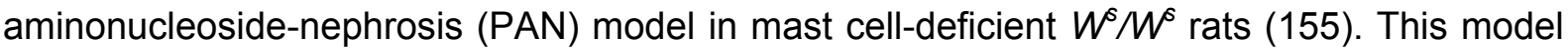
is characterized by the development of diffuse tubulointerstitial fibrosis over weeks with ECM expansion and increases in interstitial macrophages and $T$ cells (156). Following administration of puromycin disease developed in both groups as shown by increased levels of urinary protein excretion. At six weeks proteinuria dropped with a concomitant increase in blood urea nitrogen indicating a significant loss of functional nephrons. No differences were observed in these parameters between the two groups of rats. Unexpectedly however, when fibrosis development was scored by histology and measurement of hydroxyproline levels it

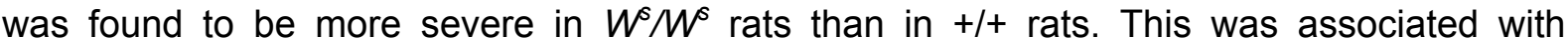
increased $\mathrm{MC}$ infiltration in the interstitium of $+/+$ rats as compared to $W^{\mathcal{S}} W^{\mathcal{s}}$ rats, while the number of other inflammatory cells (macrophages and T cells) was similar. Interestingly, the mRNA levels of two profibrotic cytokines IL-4 and TGF- $\beta 1$ were higher in the MC-deficient rats in spite of the fact that these can be produced also by MC. Further analysis revealed that heparin a major proteoglycan secreted by MC could inhibit TGF- $\beta 1$ production by renal fibroblasts in vitro providing a possible explanation for the observed inhibition. Taken together, these data indicate that $M C$ are not in a major way contributing to the pathophysiology in PAN, but rather that they may exert a slightly protective effect. The latter could implicate the inhibition of TGF- $\beta 1$ production by MC-released heparin.

Unilateral ureteral obstruction (UUO) is another representative model of tubulointerstitial renal fibrosis that have many readily quantifiable cellular and molecular events during the initiation and progression of renal fibrosis such as inflammation and apoptosis (149). Our preliminary data obtained by comparing $W / W^{N}$ mice with $+/+$ mice after 
UUO have yielded similar conclusions as we do not detect significant differences in renal inflammation and fibrosis after UUO between MC-deficient mice and +/+ mice (Kanamaru et al, unpublished).

Taken together, although MC are significantly increased in kidney disease and have the potential to participate in profibrotic inflammatory mechanisms, the available data so far suggest that they may not play a significant role in tubulointerstitial fibrosis or if they play a role they may have a slight protective effect that may be attributed to their capacity to decrease the production of profibrotic cytokines and/or promote increased remodeling functions.

\section{Concluding remarks}

Kidney diseases although induced by a variety of mechanisms have in common the development of an inflammatory response that is characterized by a complex interaction between resident kidney cells and infiltrating inflammatory cells of hematopoietic origin via produced inflammatory mediators, chemokines/cytokines and growth factors as well as cellcell interactions that mediate local tissue responses and tissue remodeling, but eventually also lead to the development of tubulointerstitial fibrosis. Evidence has been provided in the past that infiltrating hematopoietic inflammatory cells may importantly contribute to the development of pathology, but the inflammatory process may also have beneficial effects to restore normal kidney homeostasis. Among the infiltrating cells are also $\mathrm{MC}$, whose numbers are markedly increased in many kidney diseases. This has been initially interpreted as a sign of contribution to pathology. However, research in recent years, using MC-deficient animal models to dissect the interactions taking place in the kidney, have revealed a more complex picture of their actions. These may not necessarily be in accord with a pathological role of these cells. Indeed, in several of these models their presence has actually revealed that they are protective. This was most dramatically seen in an acute model of anti-GBM-induced GN, where their presence could strongly reduce the mortality. This is attributed to their capacity to immediately activate repair and remodeling functions that in addition of being induced locally 
may also be provided through systemic activation of MC. This confirms and underlines their role as sentinels for the restoration of homeostatic function in the body. Their protective action may also involve their capacity to regulate immune responses for example through their capacity to induce regulatory $\mathrm{T}$ cells that limit the infiltration with autoreactive $\mathrm{T}$ cells. MC cells may also have some beneficial actions in the long term for example by their capacity to activate tissue remodeling and to neutralize fibrosis-promoting mechanisms. However, given the complexity of the engaged inflammatory response, which often represents a double-edged sword that rapidly can turn the opposite way it is not without danger that $\mathrm{MC}$ engage their inflammatory effector responses, which in the long term can also lead to destruction. This is exemplified by the fact that different outcomes (protection versus aggravation) are observed in related animal models of kidney disease. Similarly, while the action of proteases may initially be beneficial, the induction of fibrosis-promoting angiotensin II independent of the usual rennin-angiotensin II pathway may also demonstrate the limits of adaptive responses for the installment of normal tissue homeostasis. Thus, it is likely the global physiological context involving also other cells and tissues that will determine the final action of $\mathrm{MC}$ in the development of kidney disease.

\section{Acknowledgements}

UB and MB were supported by the Fondation de Recherche Médicale (program Défis de la Recherche en Allergologie). The research project of UB and LS has been supported by a Marie Curie Early Stage Research Training Fellowship of the European Community's Sixth Framework Programme under contract number 504926 


\section{References}

1. Clynes R, Dumitru C, Ravetch JV. Uncoupling of immune complex formation and kidney damage in autoimmune glomerulonephritis. Science. 1998;279(5353):1052-4.

2. Eddy A. Role of cellular infiltrates in response to proteinuria. Am J Kidney Dis. 2001 Jan;37(1 Suppl 2):S25-9.

3. Galkina E, Ley K. Leukocyte recruitment and vascular injury in diabetic nephropathy. J Am Soc Nephrol. 2006 Feb;17(2):368-77.

4. Galli SJ, Kalesnikoff J, Grimbaldeston MA, Piliponsky AM, Williams CM, Tsai M. Mast cells as "tunable" effector and immunoregulatory cells: recent advances. Annu Rev Immunol. 2005;23:749-86.

5. Lee DM, Friend DS, Gurish MF, Benoist C, Mathis D, Brenner MB. Mast cells: a cellular link between autoantibodies and inflammatory arthritis. Science. 2002 Sep 6;297(5587):1689-92.

6. Bradding P, Walls AF, Holgate ST. The role of the mast cell in the pathophysiology of asthma. J Allergy Clin Immunol. 2006 Jun;117(6):1277-84.

7. Marshall JS. Mast-cell responses to pathogens. Nat Rev Immunol. 2004 Oct;4(10):787-99.

8. Maurer M, Wedemeyer J, Metz M, Piliponsky AM, Weller K, Chatterjea D, et al. Mast cells promote homeostasis by limiting endothelin-1-induced toxicity. Nature. 2004 Nov 25;432(7016):512-6.

9. Metz M, Piliponsky AM, Chen CC, Lammel V, Abrink M, Pejler G, et al. Mast cells can enhance resistance to snake and honeybee venoms. Science. 2006 Jul 28;313(5786):526-30.

10. Bankl HC, Valent P. Mast cells, thrombosis, and fibrinolysis: the emerging concept. Thromb Res. 2002 Feb 15;105(4):359-65.

11. Roberts IS, Brenchley PE. Mast cells: the forgotten cells of renal fibrosis. J Clin Pathol. 2000 Nov;53(11):858-62.

12. Eddy AA. Mast cells find their way to the kidney. Kidney Int. 2001 Jul;60(1):375-7.

13. Ehara T, Shigematsu H. Mast cells in the kidney. Nephrology (Carlton). 2003 Jun;8(3):130-8.

14. Barker DF, Hostikka SL, Zhou J, Chow LT, Oliphant AR, Gerken SC, et al. Identification of mutations in the COL4A5 collagen gene in Alport syndrome. Science. 1990 Jun 8;248(4960):1224-7. 15. Roselli S, Moutkine I, Gribouval O, Benmerah A, Antignac C. Plasma membrane targeting of podocin through the classical exocytic pathway: effect of NPHS2 mutations. Traffic. 2004 Jan;5(1):3744.

16. Moura IC, Centelles MN, Arcos-Fajardo M, Malheiros DM, Collawn JF, Cooper MD, et al. Identification of the transferrin receptor as a novel immunoglobulin (Ig)A1 receptor and its enhanced expression on mesangial cells in IgA nephropathy. J Exp Med. 2001;194(4):417-25.

17. Kalluri R, Gunwar S, Reeders ST, Morrison KC, Mariyama M, Ebner KE, et al. Goodpasture syndrome. Localization of the epitope for the autoantibodies to the carboxyl-terminal region of the alpha 3(IV) chain of basement membrane collagen. J Biol Chem. 1991 Dec 15;266(35):24018-24. 18. Borza DB, Netzer KO, Leinonen A, Todd P, Cervera J, Saus J, et al. The goodpasture autoantigen. Identification of multiple cryptic epitopes on the NC1 domain of the alpha3(IV) collagen chain. J Biol Chem. 2000 Feb 25;275(8):6030-7.

19. Perry GJ, Elston T, Khouri NA, Chan TM, Cameron JS, Frampton G. Antiendothelial cell antibodies in lupus: correlations with renal injury and circulating markers of endothelial damage. $Q \mathrm{~J}$ Med. 1993 Nov;86(11):727-34.

20. Ronco $P$, Debiec $H$, Guigonis V. Mechanisms of disease: Alloimmunization in renal diseases. Nat Clin Pract Nephrol. 2006 Jul;2(7):388-97.

21. Daskalakis N, Winn MP. Focal and segmental glomerulosclerosis: varying biologic mechanisms underlie a final histopathologic end point. Semin Nephrol. 2006 Mar;26(2):89-94.

22. Weber S, Tonshoff B. Recurrence of focal-segmental glomerulosclerosis in children after renal transplantation: clinical and genetic aspects. Transplantation. 2005 Sep 27;80(1 Suppl):S128-34.

23. Rougier N, Kazatchkine MD, Rougier JP, Fremeaux-Bacchi V, Blouin J, Deschenes G, et al. Human complement factor $\mathrm{H}$ deficiency associated with hemolytic uremic syndrome. J Am Soc Nephrol. 1998 Dec;9(12):2318-26.

24. Coppo R, Mene P. [Glomerulonephritis and renal sclerosis: new therapeutic proposals (review)]. G Ital Nefrol. 2004 May-Jun;21(3):217-24.

25. Fremeaux-Bacchi V, Dragon-Durey MA, Blouin J, Vigneau C, Kuypers D, Boudailliez B, et al. Complement factor I: a susceptibility gene for atypical haemolytic uraemic syndrome. J Med Genet. 2004 Jun;41(6):e84.

26. Riser BL, Cortes P, Yee J, Sharba AK, Asano K, Rodriguez-Barbero A, et al. Mechanical strain- and high glucose-induced alterations in mesangial cell collagen metabolism: role of TGF-beta. J Am Soc Nephrol. 1998 May;9(5):827-36. 
27. Essig M, Terzi F, Burtin M, Friedlander G. Mechanical strains induced by tubular flow affect the phenotype of proximal tubular cells. Am J Physiol Renal Physiol. 2001 Oct;281(4):F751-62.

28. Suzuki Y, Shirato I, Okumura K, Ravetch JV, Takai T, Tomino Y, et al. Distinct contribution of Fc receptors and angiotensin II-dependent pathways in anti-GBM glomerulonephritis [In Process Citation]. Kidney Int. 1998;54(4):1166-74.

29. Park SY, Ueda S, Ohno H, Hamano Y, Tanaka M, Shiratori T, et al. Resistance of Fc receptordeficient mice to fatal glomerulonephritis. J Clin Invest. 1998 Sep 15;102(6):1229-38.

30. Fujii T, Hamano Y, Ueda S, Akikusa B, Yamasaki S, Ogawa M, et al. Predominant role of FcgammaRIII in the induction of accelerated nephrotoxic glomerulonephritis. Kidney Int. 2003 Oct;64(4):1406-16.

31. Kaneko Y, Nimmerjahn F, Madaio MP, Ravetch JV. Pathology and protection in nephrotoxic nephritis is determined by selective engagement of specific Fc receptors. J Exp Med. 2006 Mar 20;203(3):789-97.

32. Le Hir M, Haas C, Marino M, Ryffel B. Prevention of crescentic glomerulonephritis induced by anti-glomerular membrane antibody in tumor necrosis factor-deficient mice. Lab Invest. 1998 Dec;78(12):1625-31.

33. Timoshanko JR, Sedgwick JD, Holdsworth SR, Tipping PG. Intrinsic renal cells are the major source of tumor necrosis factor contributing to renal injury in murine crescentic glomerulonephritis. J Am Soc Nephrol. 2003 Jul;14(7):1785-93.

34. Rosenkranz AR, Mendrick DL, Cotran RS, Mayadas TN. P-selectin deficiency exacerbates experimental glomerulonephritis: a protective role for endothelial P-selectin in inflammation. J Clin Invest. 1999 Mar;103(5):649-59.

35. Tang T, Rosenkranz A, Assmann KJ, Goodman MJ, Gutierrez-Ramos JC, Carroll MC, et al. A role for Mac-1 (CDIlb/CD18) in immune complex-stimulated neutrophil function in vivo: Mac-1 deficiency abrogates sustained Fcgamma receptor-dependent neutrophil adhesion and complementdependent proteinuria in acute glomerulonephritis. J Exp Med. 1997 Dec 1;186(11):1853-63.

36. Sheerin NS, Springall T, Abe K, Sacks SH. Protection and injury: the differing roles of complement in the development of glomerular injury. Eur J Immunol. 2001 Apr;31(4):1255-60.

37. Johnson RJ, Floege J, Yoshimura A, lida H, Couser WG, Alpers CE. The activated mesangial cell: a glomerular "myofibroblast"? J Am Soc Nephrol. 1992 Apr;2(10 Suppl):S190-7.

38. Kalluri R, Neilson EG. Epithelial-mesenchymal transition and its implications for fibrosis. J Clin Invest. 2003 Dec;112(12):1776-84.

39. Abbate M, Zoja C, Remuzzi G. How Does Proteinuria Cause Progressive Renal Damage? J Am Soc Nephrol. 2006 Oct 11.

40. Nangaku M, Pippin J, Couser WG. Complement membrane attack complex (C5b-9) mediates interstitial disease in experimental nephrotic syndrome. J Am Soc Nephrol. 1999 Nov;10(11):2323-31.

41. Persy VP, Verhulst A, Ysebaert DK, De Greef KE, De Broe ME. Reduced postischemic macrophage infiltration and interstitial fibrosis in osteopontin knockout mice. Kidney Int. 2003 Feb;63(2):543-53.

42. Kitagawa K, Wada T, Furuichi K, Hashimoto H, Ishiwata $\mathrm{Y}$, Asano M, et al. Blockade of CCR2 ameliorates progressive fibrosis in kidney. Am J Pathol. 2004 Jul;165(1):237-46.

43. Sato M, Muragaki Y, Saika S, Roberts AB, Ooshima A. Targeted disruption of TGFbeta1/Smad3 signaling protects against renal tubulointerstitial fibrosis induced by unilateral ureteral obstruction. J Clin Invest. 2003 Nov;112(10):1486-94.

44. Fan JM, Ng YY, Hill PA, Nikolic-Paterson DJ, Mu W, Atkins RC, et al. Transforming growth factor-beta regulates tubular epithelial-myofibroblast transdifferentiation in vitro. Kidney Int. 1999 Oct;56(4):1455-67.

45. Moeller MJ, Soofi A, Hartmann I, Le Hir M, Wiggins R, Kriz W, et al. Podocytes populate cellular crescents in a murine model of inflammatory glomerulonephritis. J Am Soc Nephrol. 2004 Jan;15(1):61-7.

46. Barisoni L, Kriz W, Mundel P, D'Agati V. The dysregulated podocyte phenotype: a novel concept in the pathogenesis of collapsing idiopathic focal segmental glomerulosclerosis and HIVassociated nephropathy. J Am Soc Nephrol. 1999 Jan;10(1):51-61.

47. Floege J, Johnson RJ, Gordon K, Yoshimura A, Campbell C, Iruela-Arispe L, et al. Altered glomerular extracellular matrix synthesis in experimental membranous nephropathy. Kidney Int. 1992 Sep;42(3):573-85.

48. Kagami S, Border WA, Miller DE, Noble NA. Angiotensin II stimulates extracellular matrix protein synthesis through induction of transforming growth factor-beta expression in rat glomerular mesangial cells. J Clin Invest. 1994 Jun;93(6):2431-7. 
49. Kanalas JJ, Hopfer U. Effect of TGF-beta 1 and TNF-alpha on the plasminogen system of rat proximal tubular epithelial cells. J Am Soc Nephrol. 1997 Feb;8(2):184-92.

50. Kitching AR, Holdsworth SR, Ploplis VA, Plow EF, Collen D, Carmeliet P, et al. Plasminogen and plasminogen activators protect against renal injury in crescentic glomerulonephritis. J Exp Med. 1997 Mar 3;185(5):963-8.

51. Savill J, Smith J, Sarraf C, Ren Y, Abbott F, Rees A. Glomerular mesangial cells and inflammatory macrophages ingest neutrophils undergoing apoptosis. Kidney Int. 1992 Oct;42(4):92436 .

52. Bellingan GJ, Caldwell H, Howie SE, Dransfield I, Haslett C. In vivo fate of the inflammatory macrophage during the resolution of inflammation: inflammatory macrophages do not die locally, but emigrate to the draining lymph nodes. J Immunol. 1996 Sep 15;157(6):2577-85.

53. Baker AJ, Mooney A, Hughes J, Lombardi D, Johnson RJ, Savill J. Mesangial cell apoptosis: the major mechanism for resolution of glomerular hypercellularity in experimental mesangial proliferative nephritis. J Clin Invest. 1994 Nov;94(5):2105-16.

54. Shimizu A, Kitamura H, Masuda Y, Ishizaki M, Sugisaki Y, Yamanaka N. Rare glomerular capillary regeneration and subsequent capillary regression with endothelial cell apoptosis in progressive glomerulonephritis. Am J Pathol. 1997 Nov;151(5):1231-9.

55. Wiggins JE, Goyal M, Sanden SK, Wharram BL, Shedden KA, Misek DE, et al. Podocyte hypertrophy, "adaptation," and "decompensation" associated with glomerular enlargement and glomerulosclerosis in the aging rat: prevention by calorie restriction. J Am Soc Nephrol. 2005 Oct;16(10):2953-66.

56. Ichikawa I, Ma J, Motojima M, Matsusaka T. Podocyte damage damages podocytes: autonomous vicious cycle that drives local spread of glomerular sclerosis. Curr Opin Nephrol Hypertens. 2005 May;14(3):205-10.

57. Colvin RB, Dvorak AM, Dvorak HF. Mast cells in the cortical tubular epithelium and interstitium in human renal disease. Hum Pathol. 1974 May;5(3):315-26.

58. Pavone-Macaluso M. Tissue mast cells in renal diseases. Acta Pathol Microbiol Scand. 1960;50:337-46.

59. Veilleux R. Mast cell increase in the duodenum and kidney of magnesium-deficient rats. Lab Invest. $1975 \mathrm{Jul} ; 33(1): 80-7$.

60. Lajoie G, Nadasdy T, Laszik Z, Blick KE, Silva FG. Mast cells in acute cellular rejection of human renal allografts. Mod Pathol. 1996 Dec;9(12):1118-25.

61. Rüger BM, Hasan Q, Greenhill NS, Davis PF, Dunbar PR, Neale TJ. Mast cells and type VIII collagen in human diabetic nephropathy. Diabetologia. 1996 Oct;39(10):1215-22.

62. Beil WJ, Fureder W, Wiener H, Grossschmidt K, Maier U, Schedle A, et al. Phenotypic and functional characterization of mast cells derived from renal tumor tissues. Exp Hematol. 1998 Feb;26(2):158-69.

63. Yamada M, Ueda M, Naruko T, Tanabe S, Han YS, Ikura Y, et al. Mast cell chymase expression and mast cell phenotypes in human rejected kidneys. Kidney Int. 2001 Apr;59(4):1374-81. 64. Toth T, Toth-Jakatics R, Jimi S, Ihara M, Urata H, Takebayashi S. Mast cells in rapidly progressive glomerulonephritis. J Am Soc Nephrol. 1999 Jul;10(7):1498-505.

65. Ehara T, Shigematsu H. Contribution of mast cells to the tubulointerstitial lesions in IgA nephritis. Kidney Int. 1998 Nov;54(5):1675-83.

66. Hiromura K, Kurosawa M, Yano S, Naruse T. Tubulointerstitial mast cell infiltration in glomerulonephritis. Am J Kidney Dis. 1998 Oct;32(4):593-9.

67. Danilewicz M, Wagrowska-Danilewicz M. Immunohistochemical analysis of the interstitial mast cells in acute rejection of human renal allografts. Med Sci Monit. 2004 May;10(5):BR151-6.

68. Danilewicz M, Wagrowska-Danilewicz M. Quantitative analysis of interstitial mast cells in lupus and non-lupus membranous glomerulopathy. Pol J Pathol. 2001;52(4):211-7.

69. Kitoh T, Ishikawa H, Ishii T, Nakagawa S. Elevated SCF levels in the serum of patients with chronic renal failure. $\mathrm{Br} \mathrm{J}$ Haematol. $1998 \mathrm{Sep}$;02(5):1151-6.

70. Otsubo S, Nitta K, Uchida K, Yumura W, Nihei H. Mast cells and tubulointerstitial fibrosis in patients with ANCA-associated glomerulonephritis. Clin Exp Nephrol. 2003 Mar;7(1):41-7.

71. El-Koraie AF, Baddour NM, Adam AG, El Kashef EH, El Nahas AM. Role of stem cell factor and mast cells in the progression of chronic glomerulonephritides. Kidney Int. 2001 Jul;60(1):167-72.

72. El Kossi MM, El Nahas AM. Stem cell factor and crescentic glomerulonephritis. Am J Kidney Dis. 2003 Apr;41(4):785-95.

73. Townsend JM, Fallon GP, Matthews JD, Smith P, Jolin EH, McKenzie NA. IL-9-deficient mice establish fundamental roles for IL-9 in pulmonary mastocytosis and goblet cell hyperplasia but not T cell development. Immunity. 2000 Oct;13(4):573-83. 
74. Godfraind C, Louahed J, Faulkner H, Vink A, Warnier G, Grencis R, et al. Intraepithelial infiltration by mast cells with both connective tissue-type and mucosal-type characteristics in gut, trachea, and kidneys of IL-9 transgenic mice. J Immunol. 1998 Apr 15;160(8):3989-96.

75. Dvorak AM, Tepper RI, Weller PF, Morgan ES, Estrella P, Monahan-Earley RA, et al. Piecemeal degranulation of mast cells in the inflammatory eyelid lesions of interleukin-4 transgenic mice. Evidence of mast cell histamine release in vivo by diamine oxidase-gold enzyme-affinity ultrastructural cytochemistry. Blood. 1994 Jun 15;83(12):3600-12.

76. Juremalm M, Nilsson G. Chemokine receptor expression by mast cells. Chem Immunol Allergy. 2005;87:130-44.

77. Toda M, Dawson M, Nakamura T, Munro PM, Richardson RM, Bailly M, et al. Impact of engagement of FcepsilonRI and CC chemokine receptor 1 on mast cell activation and motility. J Biol Chem. 2004 Nov 12;279(46):48443-8.

78. Romagnani P, De Paulis A, Beltrame C, Annunziato F, Dente V, Maggi E, et al. Tryptasechymase double-positive human mast cells express the eotaxin receptor CCR3 and are attracted by CCR3-binding chemokines. Am J Pathol. 1999 Oct;155(4):1195-204.

79. Gruber BL, Marchese MJ, Kew RR. Transforming growth factor-beta 1 mediates mast cell chemotaxis. J Immunol. 1994 Jun 15;152(12):5860-7.

80. Trachtman H, Tejani A, Keyzer JJ, Wolthers BG, Oosting E. Urinary histamine excretion in proteinuric states. Nephron. 1987;47(1):12-6.

81. Payne V, Kam PC. Mast cell tryptase: a review of its physiology and clinical significance. Anaesthesia. 2004 Jul;59(7):695-703.

82. Akers IA, Parsons M, Hill MR, Hollenberg MD, Sanjar S, Laurent GJ, et al. Mast cell tryptase stimulates human lung fibroblast proliferation via protease-activated receptor-2. Am J Physiol Lung Cell Mol Physiol. 2000 Jan;278(1):L193-201.

83. Cairns JA, Walls AF. Mast cell tryptase stimulates the synthesis of type I collagen in human lung fibroblasts. J Clin Invest. 1997 Mar 15;99(6):1313-21.

84. Kondo S, Kagami S, Kido H, Strutz F, Muller GA, Kuroda Y. Role of mast cell tryptase in renal interstitial fibrosis. J Am Soc Nephrol. 2001 Aug;12(8):1668-76.

85. Schwartz LB, Bradford TR, Littman BH, Wintroub BU. The fibrinogenolytic activity of purified tryptase from human lung mast cells. J Immunol. 1985 Oct;135(4):2762-7.

86. Thomas VA, Wheeless CJ, Stack MS, Johnson DA. Human mast cell tryptase fibrinogenolysis: kinetics, anticoagulation mechanism, and cell adhesion disruption. Biochemistry. 1998 Feb 24;37(8):2291-8.

87. Drew AF, Tucker HL, Liu H, Witte DP, Degen JL, Tipping PG. Crescentic glomerulonephritis is diminished in fibrinogen-deficient mice. Am J Physiol Renal Physiol. 2001 Dec;281(6):F1157-63.

88. Tchougounova E, Pejler G, Abrink M. The chymase, mouse mast cell protease 4, constitutes the major chymotrypsin-like activity in peritoneum and ear tissue. A role for mouse mast cell protease 4 in thrombin regulation and fibronectin turnover. J Exp Med. 2003 Aug 4;198(3):423-31.

89. Tchougounova E, Lundequist A, Fajardo I, Winberg JO, Abrink M, Pejler G. A key role for mast cell chymase in the activation of pro-matrix metalloprotease-9 and pro-matrix metalloprotease-2. J Biol Chem. 2005 Mar 11;280(10):9291-6.

90. Frank BT, Rossall JC, Caughey GH, Fang KC. Mast cell tissue inhibitor of metalloproteinase-1 is cleaved and inactivated extracellularly by alpha-chymase. J Immunol. 2001 Feb 15;166(4):2783-92. 91. Benigni A, Perico N, Remuzzi G. Endothelin antagonists and renal protection. J Cardiovasc Pharmacol. 2000;35(4 Suppl 2):S75-8.

92. Urata H, Kinoshita A, Misono KS, Bumpus FM, Husain A. Identification of a highly specific chymase as the major angiotensin II-forming enzyme in the human heart. J Biol Chem. 1990 Dec 25;265(36):22348-57.

93. Ruiz-Ortega M, Esteban V, Ruperez M, Sanchez-Lopez E, Rodriguez-Vita J, Carvajal G, et al. Renal and vascular hypertension-induced inflammation: role of angiotensin II. Curr Opin Nephrol Hypertens. 2006 Mar;15(2):159-66.

94. Wei CC, Tian B, Perry G, Meng QC, Chen YF, Oparil S, et al. Differential ANG II generation in plasma and tissue of mice with decreased expression of the ACE gene. Am J Physiol Heart Circ Physiol. 2002 Jun;282(6):H2254-8.

95. Scudamore CL, Jepson MA, Hirst BH, Miller HR. The rat mucosal mast cell chymase, RMCPII, alters epithelial cell monolayer permeability in association with altered distribution of the tight junction proteins ZO-1 and occludin. Eur J Cell Biol. 1998 Apr;75(4):321-30.

96. Lever R, Page C. Glycosaminoglycans, airways inflammation and bronchial hyperresponsiveness. Pulm Pharmacol Ther. 2001;14(3):249-54. 
97. Clarkson MR, McGinty A, Godson C, Brady HR. Leukotrienes and lipoxins: lipoxygenasederived modulators of leukocyte recruitment and vascular tone in glomerulonephritis. Nephrol Dial Transplant. 1998 Dec;13(12):3043-51.

98. Ott VL, Cambier JC, Kappler J, Marrack P, Swanson BJ. Mast cell-dependent migration of effector CD8+ T cells through production of leukotriene B4. Nat Immunol. 2003 Oct;4(10):974-81.

99. Nakae S, Suto H, Kakurai M, Sedgwick JD, Tsai M, Galli SJ. Mast cells enhance T cell activation: Importance of mast cell-derived TNF. Proc Natl Acad Sci U S A. 2005 May 3;102(18):646772.

100. Lu LF, Lind EF, Gondek DC, Bennett KA, Gleeson MW, Pino-Lagos K, et al. Mast cells are essential intermediaries in regulatory T-cell tolerance. Nature. 2006 Aug 31;442(7106):997-1002.

101. Wilson C. Renal response to glomerular injury. In: BM B, editor. 5th ed ed. Philadelphia: WB Saunders; 1996. p. 1253-391.

102. Tipping PG, Holdsworth SR. T cells in crescentic glomerulonephritis. J Am Soc Nephrol. 2006 May;17(5):1253-63.

103. Wolf $D$, Hochegger K, Wolf AM, Rumpold HF, Gastl G, Tilg H, et al. CD4+CD25+ regulatory T cells inhibit experimental anti-glomerular basement membrane glomerulonephritis in mice. J Am Soc Nephrol. 2005 May;16(5):1360-70.

104. Kanamaru Y, Scandiuzzi L, Essig M, Brochetta C, Guerin-Marchand C, Tomino Y, et al. Mast cell-mediated remodeling and fibrinolytic activity protect against fatal glomerulonephritis. J Immunol. 2006 May 1;176(9):5607-15.

105. Hochegger K, Siebenhaar F, Vielhauer V, Heininger D, Mayadas TN, Mayer G, et al. Role of mast cells in experimental anti-glomerular basement membrane glomerulonephritis. Eur J Immunol. 2005 Oct;35(10):3074-82.

106. Timoshanko JR, Kitching R, Semple TJ, Tipping PG, Holdsworth SR. A pathogenetic role for mast cells in experimental crescentic glomerulonephritis. J Am Soc Nephrol. 2006 Jan;17(1):150-9.

107. Blank U, Rivera J. The ins and outs of IgE-dependent mast-cell exocytosis. Trends Immunol. 2004 May;25(5):266-73.

108. Camussi G, Picollo G, Novelli M, Ragni R. Role of mastocyte dependent vasopermeabilization on immune complex deposition in lupus erythematosus glomerulonephritis. Panminerva Med. 1977 Sep-Oct;19(5):303-5.

109. Ravinal RC, Costa RS, Coimbra TM, Dantas M, dos Reis MA. Mast cells, TGF-beta1 and myofibroblasts expression in lupus nephritis outcome. Lupus. 2005;14(10):814-21.

110. Lin L, Gerth AJ, Peng SL. Susceptibility of mast cell-deficient W/Wv mice to pristane-induced experimental lupus nephritis. Immunol Lett. 2004 Feb 15;91(2-3):93-7.

111. Ooi BS, Pesce AJ, First MR, Pollak VE, Bernstein IL, Jao W. IgE levels in interstitial nephritis. Lancet. 1974 Jun 22;1(7869):1254-6.

112. Laurent J, Lagrue G, Sobel A. Increased serum IgE levels in patients with lupus nephritis. Am J Nephrol. 1986;6(5):413-4.

113. Elkayam O, Tamir R, Pick Al, Wysenbeek A. Serum IgE concentrations, disease activity, and atopic disorders in systemic lupus erythematosus. Allergy. 1995 Jan;50(1):94-6.

114. Tuma SN, Llach F, Sostrin S, Dubois EL, Massry SG. Glomerular IgE deposits in patients with lupus nephritis. Am J Nephrol. 1981;1(1):31-6.

115. Rebhun J, Quismorio F, Jr., Dubois E, Heiner DC. Systemic lupus erythematosus activity and IgE. Ann Allergy. 1983 Jan;50(1):34-6.

116. Egido J, Sanchez Crespo M, Lahoz C, Garcia R, Lopez-Trascasa M, Hernando L. Evidence of an immediate hypersensitivity mechanism in systemic lupus erythematosus. Ann Rheum Dis. 1980 Aug;39(4):312-7.

117. Desanctis AG, Fontana VJ, Spain WC. The role of allergy in nephrosis. N Y State J Med. 1956 Dec 15;56(24):3907-10.

118. Hardwicke J, Soothill JF, Squire JR, Holti G. Nephrotic syndrome with pollen hypersensitivity. Lancet. 1959 Mar 7;1(7071):500-2.

119. Sandberg DH, Bernstein CW, McIntosh RM, Carr R, Strauss J. Severe steroid-responsive nephrosis associated with hypersensitivity. Lancet. 1977 Feb 19;1(8008):388-91.

120. Laurent J, Rostoker G, Robeva R, Bruneau C, Lagrue G. Is adult idiopathic nephrotic syndrome food allergy? Value of oligoantigenic diets. Nephron. 1987;47(1):7-11.

121. Wittig HJ, Goldman AS. Nephrotic syndrome associated with inhaled allergens. Lancet. 1970 Mar 14;1(7646):542-3.

122. Yap HK, Yip WC, Lee BW, Ho TF, Teo J, Aw SE, et al. The incidence of atopy in steroidresponsive nephrotic syndrome: clinical and immunological parameters. Ann Allergy. 1983

Dec;51(6):590-4. 
123. Lagrue G, Wirquin E, Moretti JP, Hirbec G, Lagrue R, Galle P. [Serum IgE in glomerular nephropathies]. J Urol Nephrol (Paris). 1974 Sep;80(9):795-801.

124. Groshong T, Mendelson L, Mendoza S, Bazaral M, Hamburger R, Tune B. Serum IgE in patients with minimal-change nephrotic syndrome. J Pediatr. 1973 Nov;83(5):767-71.

125. Meadow SR, Sarsfield JK, Scott DG, Rajah SM. Steroid-responsive nephrotic syndrome and allergy: immunological studies. Arch Dis Child. 1981 Jul;56(7):517-24.

126. Pirotzky E, Hieblot C, Benveniste J, Laurent J, Lagrue G, Noirot C. Basophil sensitisation in idiopathic nephrotic syndrome. Lancet. 1982 Feb 13;1(8268):358-61.

127. Gerber MA, Paronetto F. IgE in glomeruli of patients with nephrotic syndrome. Lancet. 1971 May 29;1(7709):1097-9.

128. Robertson MR, Potter EV, Roberts ML, Patterson R. Immunoglobulin E in renal disease. Nephron. 1976;16(4):256-71.

129. Meadow SR, Sarsfield JK. Steroid-responsive and nephrotic syndrome and allergy: clinical studies. Arch Dis Child. 1981 Jul;56(7):509-16.

130. Eddy AA. Molecular insights into renal interstitial fibrosis. J Am Soc Nephrol. 1996 Dec;7(12):2495-508.

131. Eddy AA. Molecular basis of renal fibrosis. Pediatr Nephrol. 2000 Dec;15(3-4):290-301.

132. Okada H, Kalluri R. Cellular and molecular pathways that lead to progression and regression of renal fibrogenesis. Curr Mol Med. 2005 Aug;5(5):467-74.

133. Liu Y. Renal fibrosis: new insights into the pathogenesis and therapeutics. Kidney Int. 2006 Jan;69(2):213-7.

134. Bohle A, Wehrmann M, Mackensen-Haen S, Gise H, Mickeler E, Xiao TC, et al. Pathogenesis of chronic renal failure in primary glomerulopathies. Nephrol Dial Transplant. 1994;9 Suppl 3:4-12.

135. Austin HA, 3rd, Boumpas DT, Vaughan EM, Balow JE. Predicting renal outcomes in severe lupus nephritis: contributions of clinical and histologic data. Kidney Int. 1994 Feb;45(2):544-50.

136. Puxeddu I, Piliponsky AM, Bachelet I, Levi-Schaffer F. Mast cells in allergy and beyond. Int J Biochem Cell Biol. 2003 Dec;35(12):1601-7.

137. Huang XR, Chen WY, Truong LD, Lan HY. Chymase is upregulated in diabetic nephropathy: implications for an alternative pathway of angiotensin II-mediated diabetic renal and vascular disease. J Am Soc Nephrol. 2003 Jul; 14(7):1738-47.

138. Smith CJ, Smith JC, Finn MC. The possible role of mast cells (allergy) in the production of keloid and hypertrophic scarring. J Burn Care Rehabil. 1987 Mar-Apr;8(2):126-31.

139. Kawanami O, Ferrans VJ, Fulmer JD, Crystal RG. Ultrastructure of pulmonary mast cells in patients with fibrotic lung disorders. Lab Invest. 1979 Jun;40(6):717-34.

140. Broide DH, Smith CM, Wasserman SI. Mast cells and pulmonary fibrosis. Identification of a histamine releasing factor in bronchoalveolar lavage fluid. J Immunol. 1990 Sep 15;145(6):1838-44.

141. Bjermer L, Engstrom-Laurent A, Thunell M, Hallgren R. The mast cell and signs of pulmonary fibroblast activation in sarcoidosis. Int Arch Allergy Appl Immunol. 1987;82(3-4):298-301.

142. Joseph J, Kennedy RH, Devi S, Wang J, Joseph L, Hauer-Jensen M. Protective role of mast cells in homocysteine-induced cardiac remodeling. Am J Physiol Heart Circ Physiol. 2005 May;288(5):H2541-5.

143. Araki Y, Andoh A, Nakamura F, Tasaki K, Takenaka K, Komai Y, et al. Mast cells may not play a crucial role in the pathogenesis of experimental closed duodenal loop-induced pancreatitis in rats. Pancreas. 2002 Apr;24(3):298-302.

144. Araki $Y$, Andoh A, Fujiyama $Y$, Bamba T. Do mast cells play any role in the pathogenesis of experimental pancreatic fibrosis in rats? Pancreas. 2002 Nov;25(4):415-7.

145. Okazaki T, Hirota S, Xu ZD, Maeyama K, Nakama A, Kawano S, et al. Increase of mast cells in the liver and lung may be associated with but not a cause of fibrosis: demonstration using mast celldeficient Ws/Ws rats. Lab Invest. 1998 Nov;78(11):1431-8.

146. Nakata A, Tsujimura T, Sugihara A, Okamura H, Iwasaki T, Shinkai K, et al. Inhibition by interleukin 18 of osteolytic bone metastasis by human breast cancer cells. Anticancer Res. 1999 SepOct;19(5B):4131-8.

147. Mori $\mathrm{H}$, Kawada K, Zhang $\mathrm{P}$, Uesugi $\mathrm{Y}$, Sakamoto O, Koda A. Bleomycin-induced pulmonary fibrosis in genetically mast cell-deficient WBB6F1-W/Wv mice and mechanism of the suppressive effect of tranilast, an antiallergic drug inhibiting mediator release from mast cells, on fibrosis. Int Arch Allergy Appl Immunol. 1991;95(2-3):195-201.

148. Yu M, Tsai M, Tam SY, Jones C, Zehnder J, Galli SJ. Mast cells can promote the development of multiple features of chronic asthma in mice. J Clin Invest. 2006 Jun;116(6):1633-41. 149. Klahr S, Morrissey J. Obstructive nephropathy and renal fibrosis. Am J Physiol Renal Physiol. 2002 Nov;283(5):F861-75. 
150. Wang W, Koka V, Lan HY. Transforming growth factor-beta and Smad signalling in kidney diseases. Nephrology (Carlton). 2005 Feb;10(1):48-56.

151. de Boer WI, van Schadewijk A, Sont JK, Sharma HS, Stolk J, Hiemstra PS, et al.

Transforming growth factor beta1 and recruitment of macrophages and mast cells in airways in chronic obstructive pulmonary disease. Am J Respir Crit Care Med. 1998 Dec;158(6):1951-7.

152. Olsson N, Rak S, Nilsson G. Demonstration of mast cell chemotactic activity in

bronchoalveolar lavage fluid collected from asthmatic patients before and during pollen season. $\mathrm{J}$

Allergy Clin Immunol. 2000 Mar;105(3):455-61.

153. Li MO, Wan YY, Sanjabi S, Robertson AK, Flavell RA. Transforming growth factor-beta regulation of immune responses. Annu Rev Immunol. 2006;24:99-146.

154. Jones SE, Kelly DJ, Cox AJ, Zhang Y, Gow RM, Gilbert RE. Mast cell infiltration and chemokine expression in progressive renal disease. Kidney Int. 2003 Sep;64(3):906-13.

155. Miyazawa S, Hotta O, Doi N, Natori Y, Nishikawa K. Role of mast cells in the development of renal fibrosis: use of mast cell-deficient rats. Kidney Int. 2004 Jun;65(6):2228-37.

156. Jones CL, Buch S, Post M, McCulloch L, Liu E, Eddy AA. Pathogenesis of interstitial fibrosis in chronic purine aminonucleoside nephrosis. Kidney Int. 1991 Dec;40(6):1020-31. 


\section{Figure Legends}

\section{Fig. 1. The inflammatory circuit in kidney disease.}

Kidney disease starts with an injury of the kidney structures mostly at the level of the glomeruli or less frequently of the tubules. This engenders an inflammatory response characterized by the recruitment of inflammatory cells and their interaction with resident kidney cells and the generation of inflammatory mediators in order to counteract disease and mediate adaptive responses and tissue repair. In case inflammation does not resolve due to a strong initial damage, to chronic stimulation or to defective regulation, resident and infiltrating cells in the kidney interact in the inflammatory response to mediate disease progression by initiating the production of additional sets of inflammatory products and growth factors. These lead to epithelial-mesenchymal transition (EMT), fibroblast proliferation with collagen synthesis and ECM expansion thereby promoting nephron and vessel loss. At the same time the activation of proteases and phagocytes action participate in repair mechanisms and resolution of inflammation. Due to the loss of nephrons and blood vessels, adaptive responses take place at the level of kidney structures destined to maintain kidney function through structural hypertrophy and eventually regenerative mechanisms. The scarred kidney is now more sensitive to injury, which may further increase the risk of persistent injury. When a certain number of nephrons and vessels have been lost end-stage renal failure inevitably develops. Mast cells could participate in many steps of the inflammatory responses either through systemic activation or locally by secreting inflammatory mediators that may participate in the repair functions or on the contrary in kidney destruction and end-stage renal failure.

Fig. 2. Infiltrating $M C$ in an advanced stage (class IV) lupus nephritis patient. The picture shows MC stained immunohistochemically with an antibody to human tryptase. The low magnification (Obj. 10x, left) reveals the scattered appearance of infiltrated MC in 
interstitial areas (arrows) and sometimes close to tubules (asterix). No MC is seen in the glomeruli (G). High magnification (Obj. 40x, right) shows an agglomerate of tryptase-positive $\mathrm{MC}$ that are located close to an area with extensive mononuclear cell infiltration.

\section{Fig. 3 Hypothesis to explain the balance of MC functions in anti-GBM-induced GN.}

In the first GN model, disease develops rapidly due to the injection of strongly nephrotoxic anti-GBM antibodies and the use of an accelerated disease model with preimmunization. Here $\mathrm{MC}$ are directly protective by their ability to trigger acute effector mechanism that mediate repair and remodeling such as fibrinolysis and collagen degradation. In the second model, despite the use of a likewise accelerated model, GN develops more slowly likely due to less nephrotoxic anti-GBM antibodies used. In this case the protective effect might be indirect and involve regulatory $\mathrm{T}$ cells mobilization that dampen the development of effector $\mathrm{T}$ cell responses during the autologous phase of the disease. Such a mechanism may also be operative in the first model. In the third model, mice were not preimmunized and disease develops slowly likely requiring $\mathrm{MC}$ for efficient development of $\mathrm{TH} 1$-mediated effector mechanisms. This hypothesis underlines the two faces of MC involvement in inflammatory mechanisms. The outcome (protection or aggravation) may very much depend on the MC's pathophysiological environment. 
Table 1. Mast cell counts in normal and pathologic kidneys

\begin{tabular}{|c|c|c|c|c|}
\hline Kidney phenotype & Tryptase $+M C / m^{2}$ (a) & Chymase $+\mathbf{M C} / \mathrm{mm}^{2}(\mathrm{a})$ & $\begin{array}{l}\text { Toluid. Blue+ MC/mm² } \\
\text { and other methods }{ }^{(a)}\end{array}$ & Ref. \\
\hline Normal kidney & $\begin{array}{c}1,6 \pm 0,4^{(b)} \\
<0,05 \\
1,8 \pm 0,35 \\
7,1 \pm 1,3 \\
1,9 \pm 0,3 \\
\text { Not tested } \\
2,02 \pm 0,91\end{array}$ & $\begin{array}{r}1 \pm 0,5^{(\mathrm{b})} \\
\text { Not tested } \\
0,58 \pm 0,3 \\
1,9 \pm 0,86^{(\mathrm{d})}\end{array}$ & $\begin{array}{c}<0,05 / \text { - (c) }^{(\mathrm{c}} \\
0,7 \pm 0,2 / 1,2 \pm 0,4{ }^{(\mathrm{e})} \\
0,5 \pm 0,2 / 0^{\text {(f) }}\end{array}$ & $\begin{array}{l}(61) \\
(62) \\
(63) \\
(64) \\
(65) \\
(66) \\
(57) \\
(67)\end{array}$ \\
\hline Minimal change nephrotic syndrome & $0,8 \pm 1,6$ & & & (66) \\
\hline $\begin{array}{l}\text { Minor glomerular abnormalities (not } \\
\text { nephrotic) }\end{array}$ & $1,5 \pm 0,7$ & & & (66) \\
\hline $\begin{array}{l}\text { Menbranous proliferative } \\
\text { glomerulonephritis }\end{array}$ & $19,8 \pm 14,2$ & & & (66) \\
\hline Membranous nephropathy & $6,5 \pm 7,7$ & & & (66) \\
\hline Lupus nephritis & $12,9 \pm 15,5$ & & & (66) \\
\hline ANCA-related nephropathy & $18,5 \pm 21,1$ & & & (66) \\
\hline IgA nephropathy & $\begin{array}{c}23 \pm 2,9 \\
21,3 \pm 17,7\end{array}$ & & $2,4 \pm 0,5 / 10,2 \pm 1,4^{(e)}$ & $\begin{array}{l}(65) \\
(66)\end{array}$ \\
\hline $\begin{array}{l}\text { Rapid progressive } \\
\text { glomerulonephritis }\end{array}$ & $43,7 \pm 4,6$ & $13,8 \pm 1,86^{(d)}$ & & (64) \\
\hline Chronic glomerulonephritis & & & $14,0 \pm 3,2 / 1,3 \pm 0,4^{(f)}$ & (57) \\
\hline Diabetic nephropathy & $\begin{array}{l}12,7 \pm 9,5^{(b)} \\
33,0 \pm 33,8\end{array}$ & $10,2 \pm 8.4^{(b)}$ & & $\begin{array}{l}(61) \\
(66)\end{array}$ \\
\hline $\begin{array}{l}\text { Focal segmental glomerular } \\
\text { sclerosis }\end{array}$ & $13,4 \pm 8,3$ & & & (66) \\
\hline Benign nephrosclerosis & & & $1,6 \pm 0,4 / 0^{(f)}$ & (57) \\
\hline Malignant nephrosclerosis & & & $17,0 / 2,7^{(f)}$ & (57) \\
\hline Renal cell carcinoma & $11 \pm 14$ & $0,9 \pm 1,1$ & $11 \pm 14 / 4 \pm 4^{(c)}$ & (62) \\
\hline $\begin{array}{l}\text { Acute allograft rejection } \\
\text { Chronic allograft rejection } \\
\text { Allograft rejection: } \\
\text { Nephrectomy Specimens } \\
\text { Biopsy Specimens }\end{array}$ & $\begin{array}{c}9,1 \pm 2,4 / 13,9 \pm 3,4^{(g)} \\
9,00 / 14,6 \pm 3,64^{(g)}\end{array}$ & $\begin{array}{c}0,4 \pm 0,18 / 12,03 \pm 2,65^{(g)} \\
0,51 / 9,0 \pm 2,27^{(g)}\end{array}$ & $\begin{array}{c}0,1 \pm 0,1 / 0^{(f)} \\
12,7 \pm 1,2 / 0,1 \pm 0,1^{\text {(f) }}\end{array}$ & $\begin{array}{l}\text { (57) } \\
(67) \\
(57) \\
\\
(63) \\
(63)\end{array}$ \\
\hline Chronic pyelonephritis & & & $14,6 \pm 2,9 / 3,2 \pm 1,0^{(f)}$ & (57) \\
\hline Analgesic nephropathy & & & $28,0 / 1,7^{(f)}$ & (57) \\
\hline
\end{tabular}


Footnotes:

a) Numbers given are mean \pm SD.

b) Mast cells positive for tryptase and chymase were counted in five medium power fields (x 50) using a 25-point Zeiss (Jena, Germany) integrating grid.

c) Mast cells numbers given are after fixation in Carnoy's solution and NFF solution (Neutral Formalin Fixative: 1,5\% formalin/PBS pH 7,4), respectively.

d) Numbers given are those for MC double positive for tryptase and chymase (MC $\mathrm{MC}_{\mathrm{TC}}$ ).

e) Mast cells numbers given are after TB (Toluidine Blue) staining at $\mathrm{pH} 5$ and $\mathrm{pH} 0,5$, respectively.

f) Numbers given are intestitial and tubular mast cells counted in the cortex per 100 tubular cross sections observed in the electron microscope.

g) Numbers given are tryptase-positive mast cells which were, respectively, chymase-negative or chymase-positive. 


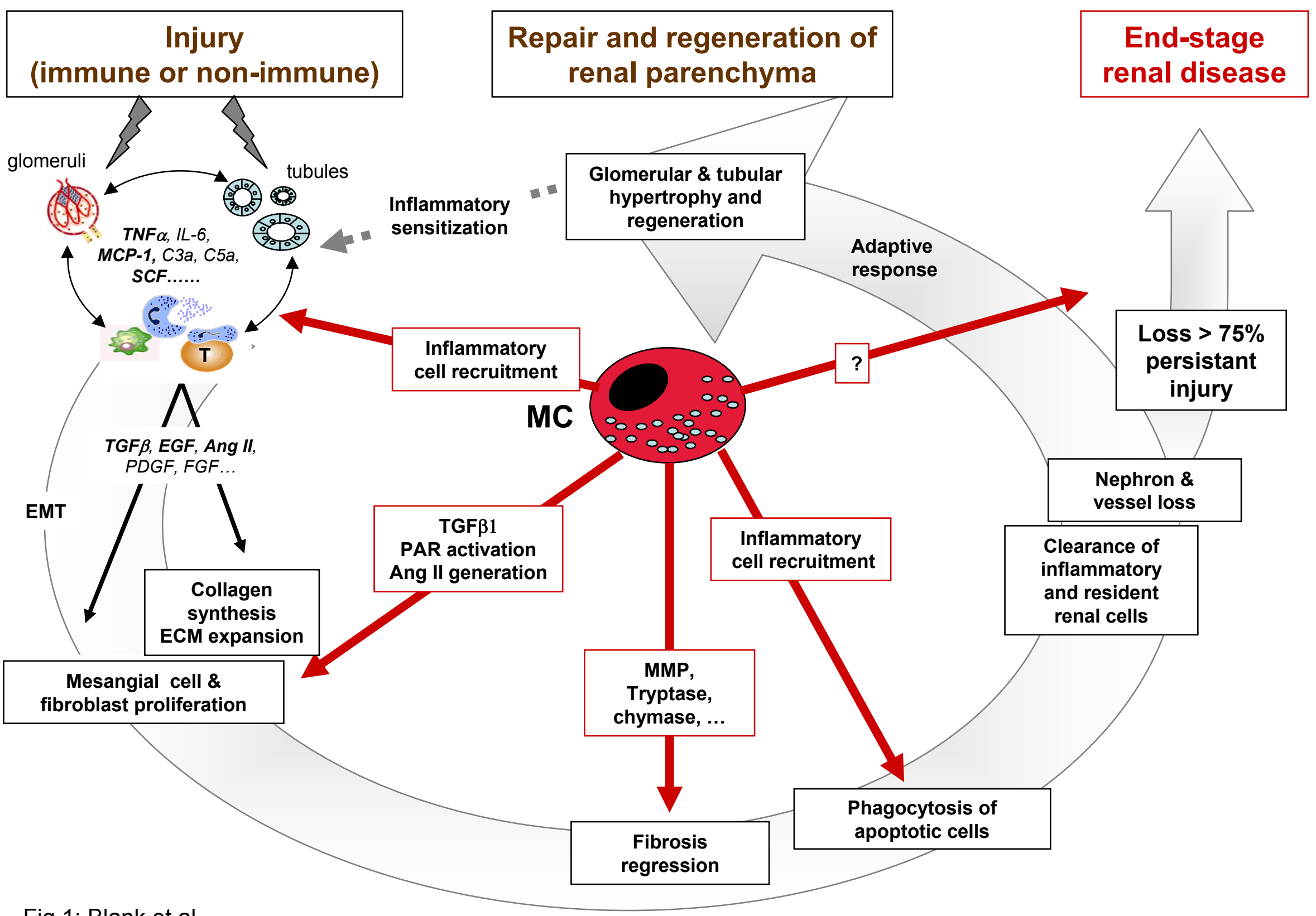

Fig.1: Blank et al 


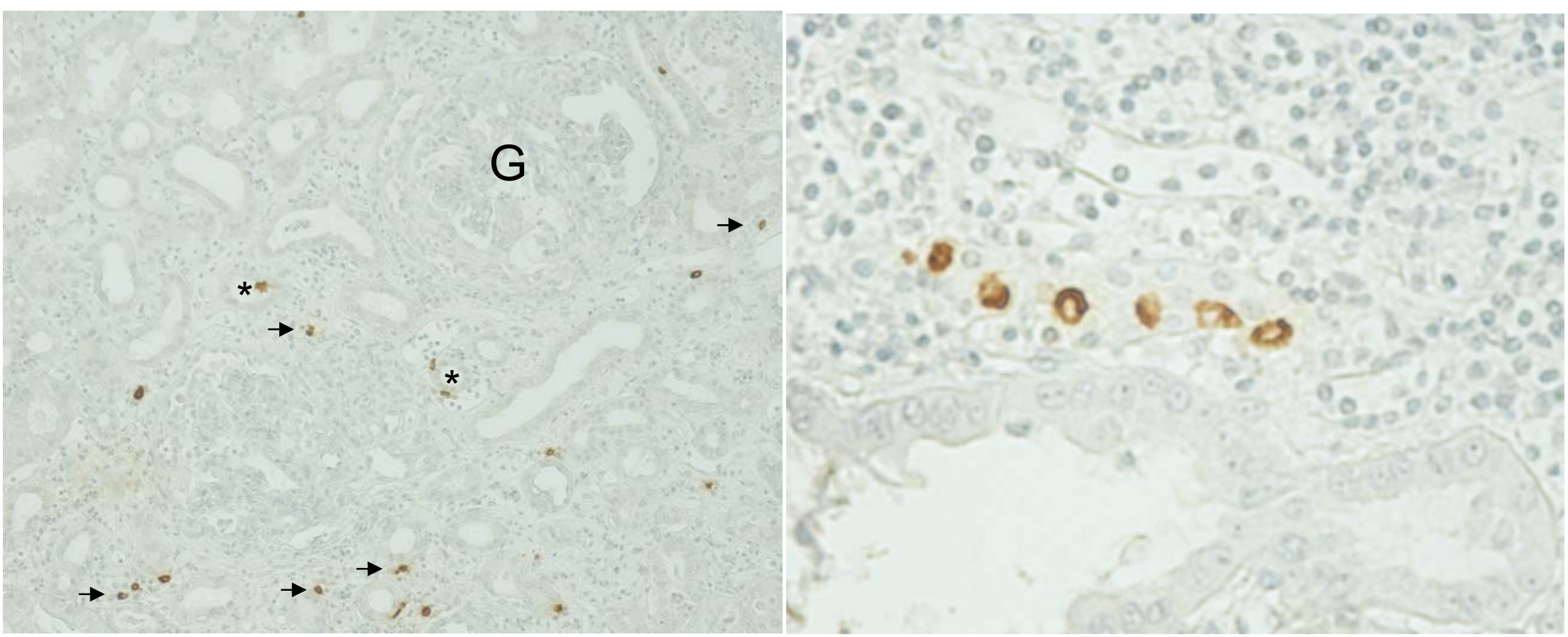

Fig.2: Blank et al 


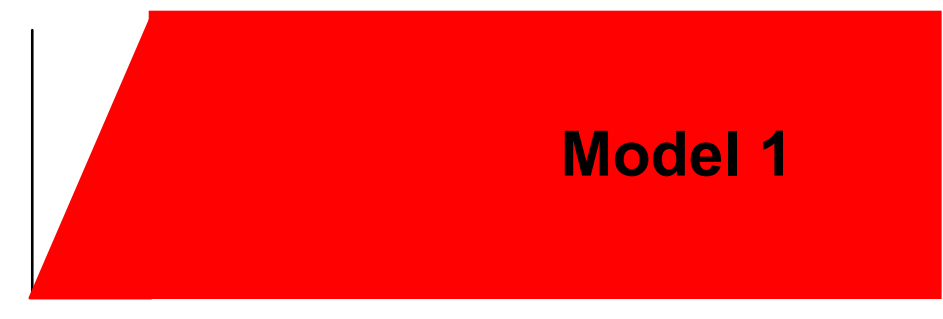

$$
\text { protection } \longrightarrow \begin{gathered}
\text { Acute effector } \\
\text { mechanisms }
\end{gathered}
$$

है

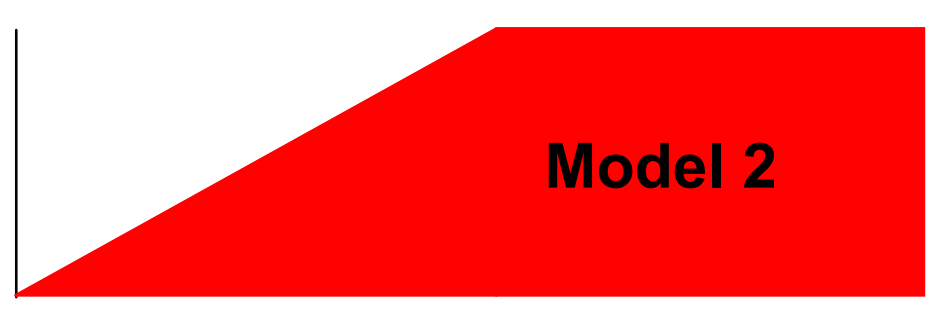

$$
\text { protection } \longrightarrow \quad \mathrm{T}_{\text {reg }}
$$

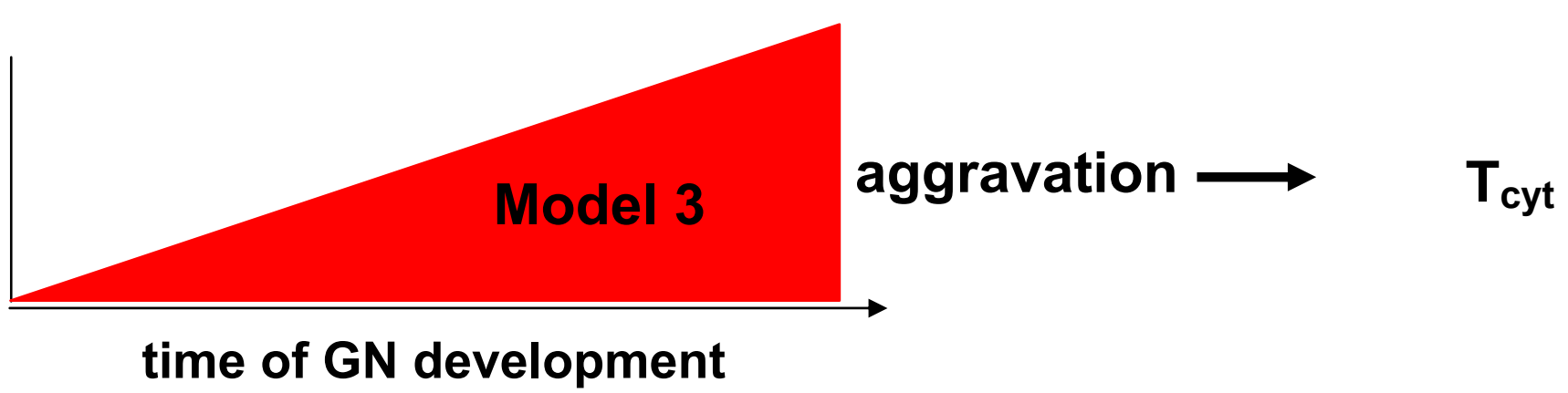

protection

MC pathophysiological environment $\downarrow \downarrow \downarrow \downarrow \downarrow \downarrow \downarrow \downarrow \downarrow \downarrow \downarrow \downarrow$

aggravation 